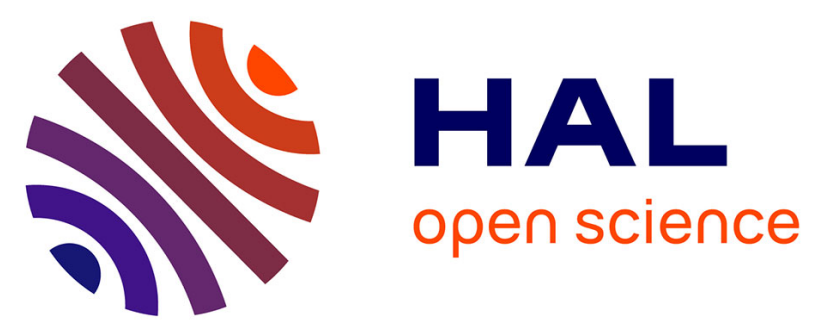

\title{
Detection methods and prevalence of transmission stages of Toxoplasma gondii , Giardia duodenalis and Cryptosporidium spp. in fresh vegetables: a review
}

Salma Berrouch, Sandie Escotte-Binet, Rajae Harrak, Antoine Huguenin, Pierre Flori, Loïc Favennec, Isabelle Villena, Jamaleddine Hafid

\section{To cite this version:}

Salma Berrouch, Sandie Escotte-Binet, Rajae Harrak, Antoine Huguenin, Pierre Flori, et al.. Detection methods and prevalence of transmission stages of Toxoplasma gondii , Giardia duodenalis and Cryptosporidium spp. in fresh vegetables: a review. Parasitology, 2020, 147 (5), pp.516-532. 10.1017/S0031182020000086 . hal-02955693

\section{HAL Id: hal-02955693}

https://hal-normandie-univ.archives-ouvertes.fr/hal-02955693

Submitted on 6 Oct 2020

HAL is a multi-disciplinary open access archive for the deposit and dissemination of scientific research documents, whether they are published or not. The documents may come from teaching and research institutions in France or abroad, or from public or private research centers.
L'archive ouverte pluridisciplinaire HAL, est destinée au dépôt et à la diffusion de documents scientifiques de niveau recherche, publiés ou non, émanant des établissements d'enseignement et de recherche français ou étrangers, des laboratoires publics ou privés. 
Detection methods and prevalence of transmission stages of Toxoplasma gondii, Giardia duodenalis and Cryptosporidium spp. in fresh vegetables: a review

Berrouch Salma ${ }^{1,2}$, Escotte-Binet Sandie ${ }^{2}$, Harrak Rajae ${ }^{3}$, Huguenin Antoine ${ }^{2}$, Flori Pierre ${ }^{4}$, Favennec Loï ${ }^{5}$, Villena Isabelle ${ }^{2+}$, Hafid Jamaleddine ${ }^{1 *}$

${ }^{1}$ Laboratory of Food, Environment and Health, Faculty of Sciences and Techniques, Marrakech, Morocco.

${ }^{2}$ Laboratory of Parasitology-Mycology, ESCAPE EA 7510, SFR CAP SANTE, University of Reims ChampagneArdenne, and CHU Reims, Hospital Maison Blanche, National Reference Centre of Toxoplasmosis, Reims, France + Isabelle Villena is equal contributor to this publication.

${ }^{3}$ Regional Laboratory for Epidemiological Diagnosis and Environmental Health, Marrakech, Morocco.

${ }^{4}$ Laboratory of Infectious Agents- Parasitology section- GIMAP, Faculty of Medicine, Saint-Etienne, France.

${ }^{5}$ Laboratory of Parasitology, EA 7510 ESCAPE, University of Rouen, CHU Rouen, National Reference Centre of Cryptosporidiosis, France.

*Corresponding author: Pr Hafid Jamaleddine. Email: hfjamal@yahoo.fr

\begin{abstract}
One of the ways of human parasitic infection is the accidental ingestion of vegetables contaminated with parasites, which represents a major human health hazard. This non-exhaustive review aims to evaluate studies carried out on five types of vegetables (lettuce, parsley, coriander, carrot and radish) since 2000, particularly the methods used for recovery, concentration, detection and identification of protozoan parasites as Toxoplasma gondii, Giardia duodenalis and Cryptosporidium spp., and the results of each work. Various studies have determined the presence of pathogenic parasites in fresh vegetables with different rates, this variation in rate depends particularly on the detection method used which is related to each parasite and each vegetable type.

The variation in parasitic prevalence in food could be due to different factors as the geographical location, the size of analyzed samples, and the methods used for parasite detection.
\end{abstract}

Key words: Toxoplasma. Giardia. Cryptosporidium. Vegetables. Detection. Prevalence of contamination. 


\section{Introduction}

T. gondii, G. duodenalis and Cryptosporidium spp. are protozoan parasites that are considered as emerging food and waterborne pathogens according to Food and Agriculture Organization of the United Nations and the World Health Organization (FAO/WHO, 2012). Sometimes, these parasites are present in the environment in high numbers in their transmission stages, which are oocysts for $T$. gondii and Cryptosporidium spp., and cysts for G. duodenalis. Therefore, these forms can contaminate water and soil and may be considered as vehicles of parasitic contamination and disease outbreak. However, these parasitic forms are not capable of multiplying as bacteria, which implies the need for sensitive methods for their detection in food matrices. The rates of parasitic contamination are different from one country to another and even between regions in the same country.

Vegetables and fruits are an important part of a balanced diet due to their nutritional value (Losio et al., 2015). Nowadays there is a global increase in the tendency to eat raw or slightly cooked vegetables, which may increase the risk of food borne infections (FAO/WHO, 2012). Parasitic diseases are an important health problem that can, in some cases, occur by the transmission of parasites to humans through the ingestion of contaminated water or foodstuffs as vegetables. Infections as giardiasis and cryptosporidiosis are usually characterized by diarrhea, stomach pain, and vomiting. The presence of these pathogens in fresh vegetables, even in very low concentrations, poses a high risk to the consumer (Ali et al., 2004). The extent of contamination depends on various factors that include among others, the use of untreated or contaminated water for irrigation, irregular hygiene practices during post-harvest handling as well as environmental pollution (Kumar et al., 2014).

In the past, the risk of human infection due to parasites was limited to distinct geographic regions, because of parasites' adaptation to definitive hosts, specific intermediate hosts and environmental conditions. These barriers have been gradually removed due to the expansion of international commerce of foodstuffs, facilitated by refrigerated transport (El Said Said, 2012). Indeed, several parasitic infections cases were linked to imported foodstuffs, for example, horse meat imported from Canada and Brazil was implicated in particular cases of toxoplasmosis in individuals in France (Pomares et al., 2011), since there are virulence differences in Toxoplasma strains which are associated to geographic localization, the exchange of fresh or chilled meat - but not frozen -may induce the spreading of such strains (Robertson et al., 2014). On another hand, imported fresh produces to non-native regions or countries were incriminated in multiple foodborne outbreaks, for example, imported raspberries from Guatemala were responsible for cyclosporiasis outbreak in Canada and the United States (Ortega and Sanchez, 2010).

The lack or the absence of adequate methods for the detection of parasites in fresh vegetables can lead to the underestimation of foodborne parasitic outbreaks or even their non-detection. In fact, standardized methods exist only for the microscopic detection of Cryptosporidium spp. and G. duodenalis in leafy green vegetables and berry fruits after immunomagnetic separation (Method 18744) (ISO, 2016). Other harmful parasites as T. gondii require the establishment of reliable and practical methods for their detection.

Existing studies on the prevalence of parasites are heterogeneous due to numerous factors, such as i) sampling methods, ii) detection procedures with different recovery efficiencies and also variable detection limits, iii) geographic locations, iv) levels of development between countries, as well as v) seasonal changes within countries.

The aim of this review is to compare the findings on me multiple studies carried out in order to analyze leafy greens (lettuce (Lactuca sativa), parsley (Petroselinum crispum), coriander (Coriandrum sativum)) and root 
vegetables (radish (Raphanus raphanistrum subsp. sativus), carrot (Daucus carota subsp. sativus)) for the presence of T. gondii and Cryptosporidium spp. oocysts and G. duodenalis cysts; this includes the methods used and the results obtained in order to demonstrate prevalence rates of parasitic contamination.

\section{Literature selection criteria}

In this review, we have evaluated the different monitoring methods of $T$. gondii, G. duodenalis and Cryptosporidium spp. in some fresh leafy green vegetables as lettuce, parsley and coriander, and root vegetables as carrot and radish, and we have listed the different described procedures used for the detection of the three protozoan in fresh vegetables and the prevalence rates reported worldwide. For this purpose, we have performed a search of the literature databases since 2000 (e.g., PubMed, ScienceDirect, and Google Scholar), in which, the terms "detection of parasites in vegetables", "prevalence of parasites in vegetables", "vegetables and protozoan parasites", "T. gondii in vegetables", "G. duodenalis in vegetables", "Cryptosporidium in vegetables", and "foodborne parasites" were applied. The obtained literature included about 200 papers relevant to the detection of protozoan and helminths parasites in various fresh vegetables. We have selected the articles investigating the presence of at least one of the parasites of interest (T. gondii, G. duodenalis or Cryptosporidium spp.), in marketed fresh vegetables, even if the studies involved other parasites. As we have also taken into account the studies reported on the detection of the three protozoan parasites, in different vegetables types including at least one of the vegetables in focus. This selection led to keeping 48 papers as represented in Table 1.

\section{Detection of parasitic transmission stages in fresh vegetables}

\section{1. sampling}

For the detection of $T$. gondii, G. duodenalis and Cryptosporidium spp. in fresh vegetables, the commonly consumed fresh vegetables in each study area were collected randomly from retail markets, supermarkets, or street vendors. Then, they were transported in plastic or nylon sterile labeled bags to the laboratory for parasitological analysis. Different types of vegetables were analyzed, especially leafy ones, as lettuce, parsley, coriander, etc.

Parasites were investigated in portions of about $10 \mathrm{~g}-1 \mathrm{~kg}$ of each vegetable depending on the studies. Three distinct steps were followed: elution, concentration and detection. The methods used to detect parasites and their prevalence in fresh vegetables, according to different studies, are summarized in Table 1.

\subsection{Elution}

The elution step aims to extract parasites from vegetable samples. It is crucial since all subsequent steps depend on the efficiency of (oo)cyst recovery. Therefore, the use of adequate elution buffers and efficient separation (isolation) methods is required to maximize the (oo)cyst recovery as well as the accuracy of the results. Various elution methods were evaluated for the elution of protozoan parasites from vegetable matrices. Indeed, Cook $e t$ al., (2006) evaluated different elution buffers (e.g., PBS [phosphate-buffered saline], $\mathrm{pH} 7.2 ; 0.1 \mathrm{M}$ tricine, $\mathrm{pH}$ 5.4; $1 \%$ lauryl sulfate; $1 \mathrm{M}$ Glycine, $\mathrm{pH} 5.5$ ) for the detection of $C$. parvum in lettuce, as they tested various elution procedures (e.g., stomaching, pulsification, rolling, orbital shaking), coupled with immunofluorescence assay (IFA). They demonstrated that the extractants and physical extraction methods influenced the percentage of recovered oocysts. According to this study, Glycine buffer '1M Glycine', $\mathrm{pH}$ of 5.5 was the cheapest and effective buffer compared to the other ones, especially when it was coupled with stomaching for $1 \mathrm{~min}$ (recovery

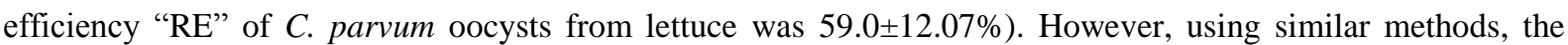
recovery of parasites from lettuce has varied as reported by Rzezutka et al., (2010) (RE of Cryptosporidium was 
19\%) and Utaaker et al., (2015) (RE were 53\% for Cryptosporidium and 33\% for Giardia), that could be related to the number of replicates tested. Noting that slight changes in the method could affect the recovery as illustrated in the finding of Amoros et al., (2010) (RE were 24.5 $\pm 3.5 \%$ for Cryptosporidium and 16.7 $\pm 8.1 \%$ for Giardia in fresh produce) when reducing the time of stomaching to 30 seconds. Otherwise, Shields et al., (2012) compared various buffers as deionized water, $1 \mathrm{M}$ Glycine, $\mathrm{pH} 5.5$, a detachment solution, and 0.1\% Alconox ${ }^{\circledR}$, to recover $C$. parvum and Cyclospora cayetanensis from lettuce, herbs and raspberries; the RE of C. parvum from spinach and raspberries using deionized water were $38.4 \pm 10.1 \%$ and $34.9 \pm 6.2 \%$, respectively, whereas there was no statistically significant difference between the deionized water and $1 \mathrm{M}$ glycine, $\mathrm{pH} 5.5$. Furthermore, they revealed that $0.1 \%$ Alconox ${ }^{\circledR}$ allowed a significant improved recovery $(72.6 \pm 6.6 \%)$ of $C$. parvum oocysts from basil. On another hand, elution buffers (EB) composed of Laureth 12, 1M Tris buffer; $\mathrm{pH}$ 7.4, EDTA and Antifoam A were also used (Robertson and Gjerde, 2000; Bethea, 2014) and evaluated when coupled with rotating and IFA, revealing a RE of $42 \%$ for Cryptosporidium, and $67 \%$ for Giardia in lettuce, Chinese leaves, and strawberries (Robertson and Gjerde, 2000). A recent study (Shapiro et al., 2019) described a method for simultaneous detection of C. parvum, G. duodenalis, T. gondii and C. cayetanensis, that coupled leafwashing with m-PCR (multiplex Polymerase Chain Reaction) allowing higher recoveries (46\% for Cryptosporidium, 38\% for Giardia and $43 \%$ for T. gondii) with $90 \%$ certainty of their detection when contamination levels ranged from 1 to 10 (oo)cysts/g of spinach, and permitting more consistent detection of parasites compared to stomaching processing. Furthermore, various studies employed physiological saline solution to detach parasites from vegetables (Daryani et al., 2008; Abougrain et al., 2010; Ezatpour et al., 2013; Benti and Gemechu, 2014; Alhabbal, 2015; Gabre and Shakir, 2016), followed by microscopic examination (Table 1) since it is a simple and low coast approach, but the RE were not determined.

The difference in recovery efficiencies (Table 2) between the different elution buffers could be stemmed from their composition and interaction with the foodstuffs tested. For lettuce, $1 \mathrm{M}$ glycine with optimal $\mathrm{pH}$ allowed for instance no excess debris formation and did not influence Cryptosporidium oocysts recovery in IMS (Cook et al., 2006), contrarily to EB that has a low molarity and a neutral pH that made the recovery suboptimal. This later could be overcome by increasing both molarity and $\mathrm{pH}$ (Cook et al., 2006). While 0.1\% Alconox ${ }^{\circledR}$ that contains both synthetic detergent surfactant agents and food additives with emulsifying and dispersing properties, allowed an efficient removal of oocysts from vegetable surfaces (Shields et al., 2012), but when used with stomaching, produced an excessive foam that interferes with oocyst recovery (Lalonde and Gajadhar, 2016a).

\subsection{Concentration}

The concentration step is usually done by centrifugation (Maikai et al., 2012; Benti and Gemechu, 2014; Avazpoor et al., 2015; Ahmad et al., 2016; Marchioro et al., 2016), as it can then be followed by isolation methods as immunomagnetic separation (IMS) (Robertson and Gjerde, 2001a; Rzezutka et al., 2010; Utaaker et al., 2017). This latter is recommended in the standardized method 18744 for Cryptosporidium spp. and G. duodenalis detection in fresh leafy green vegetables and berry fruits (ISO, 2016), but it is time consuming and expensive, thus not suitable for industrials trying to establish parasitic control for foodstuffs. In this context of minimizing the cost and the duration of sample treatment, Utaaker et al., (2015) reduced the number of IMS reagents and modified the buffering system, while others replaced the immunofluorescence method by molecular techniques. 


\subsection{Detection}

Among the described methods, direct microscopic examination, acid-fast stains as modified Ziehl-Neelsen staining (used for Cryptosporidium detection) or Lugol's Iodine stain (used to detect Giardia) were commonly used (Table 1), because of their low cost. Whereas compared to other methods, they were suboptimal for the detection of parasites. Indeed, Ramirez-Martinez et al., (2015) reported a recovery efficiency of $20 \pm 4.3 \%$ and a detection limit of 20 cysts of Giardia/g of lettuce, using light microscopy, while PCR targeting the $\beta$-giardin gene was 10-fold more sensitive. Another method is the IFA, which was used for the detection of parasites (oo)cysts in various vegetable matrices, it is in fact the method recommended by the 18744 method (ISO, 2016). The combination of immunofluorescence, size and morphology allowed to identify and recognize (oo)cysts from the other particles (Miller et al., 2006; Keserue et al., 2012). However, the auto-fluorescence of some particles present in foodstuffs matrices could interfere with labelled (oo)cysts making the IFA unsuitable for their analysis. Besides, this method was claimed to be time consuming, requiring an expensive technology and a microscopy expertise (Ahmed and Karanis, 2018). Since the IFA does not provide the genotype of detected parasites, it was coupled to PCR to improve the specificity as used by Rzezutka et al., (2010) and Utaaker et al., (2017). On the other hand, different studies have described molecular approaches that allow the detection of protozoan parasites in vegetables, these methods' efficiency is strongly correlated with the recovery of (oo)cysts from vegetables as well as the DNA extraction step. Technically this later could be performed by altering cycles of freezing/thawing, which is time consuming, or using commercial kits based on a mechanical disruption of (oo)cysts walls, that was proved to be more suitable for the DNA extraction of T. gondii (Lass et al., 2012), G. duodenalis and C. parvum from complex matrices as vegetables (Berrouch et al., data not shown). Throughout the described studies, Marchioro et al., (2016) conclude that the detection limits (LOD) of $T$. gondii in lettuce were 10 and 100 oocysts per $\mu 1$, using a PCR targeting the B1 gene and the 529 bp fragment, respectively. Taking into account that this difference was explained by the fact that the $\mathrm{B} 1$ gene consists of a highly conserved region of the genome of the parasite and is repeated 35 times while the 529 bp fragment is repeated 200-300 times in the genome and corresponds to a non-coding region (Marchioro et al., 2016). In addition, Hohweyer et al., (2016) evaluated the LOD of T. gondii, G. duodenalis and C. parvum in basil using qPCR, the results were 3 (oo)cysts/g for both C. parvum and G. duodenalis, and below 1 oocyst/g for T. gondii. Whereas Lass et al., (2012) reported a LOD of 100 oocysts T. gondii in radish, by qPCR. Lalle et al., (2018) have also assessed the LOD of this parasite in baby lettuce at 0.5 oocyst per g, using LAMP-Chromatographic Lateral-Flow Dipstick. Although this technique requires more time compared to qPCR, it requires cheaper equipment which makes it a valuable molecular test to be established in resource limited cases (Table 2).

Currently, there is one standardized method 18744 (ISO, 2016) for the detection and enumeration of Cryptosporidium and Giardia in fresh leafy green vegetables and berry fruits. However, there are many parasites as $T$. gondii which are harmful for humans and can't be monitored using this method, since there are no monoclonal antibodies for $T$. gondii oocyst walls to perform IMS separation and IFA detection. Considering the finding of Dumètre and Dardé, (2005) where the monoclonal antibody mAbs 3G4 was described and incorporated in an IMS procedure against $T$. gondii : wall, Hohweyer et al., (2016) tested the IMS Toxo method (using the monoclonal antibody mAb 3G4 coupled with Super paramagnetic beads (Activ Master Beads $(\# 02650)$ ) for two food matrices, basil and raspberries, and the mean recovery rates in basil were $0.2 \%$ 
and $35 \%$ by microscopy and qPCR, respectively, while they were $2.0 \%$ by microscopy against $29 \%$ by qPCR, in raspberries.

\section{Prevalence of $T$. gondii and Cryptosporidium spp. oocysts and $G$. duodenalis cysts in vegetables:}

As summarized in Table 1, fresh vegetables were found to be contaminated with protozoan parasites namely $T$. gondii, G. duodenalis and Cryptosporidium spp. with different rates.

\subsection{Prevalence of T. gondii oocysts:}

There have only been few studies on the prevalence of $T$. gondii in fresh produce that reported different rates of T. gondii, based on different elution methods and a variety of microscopic and molecular assays (Table 1). The contamination rates of fresh produce marketed in Canada (Lalonde and Gajadhar, 2016b) (lettuce 0\%), United States of America (lettuce 2\%, parsley 0\%) and Peru (Bethea, 2014) (lettuce 3.6\%, parsley 4.3\%) were largely lower than those reported in Egypt (Ahmad et al., 2016) (lettuce 41\%, carrot 12.2\% and parsley 5.7\%) or SaudiArabia (Al-Megrm, 2010) (leafy vegetables 6.6\%). The contamination of fresh produce with T. gondii could be affected by various factors (see section 3 below) as it could be underestimated since there is a loss of oocysts during the recovery procedures as demonstrated by Lass et al., (2012) when comparing the results of qPCR performed with DNA extracted from $T$. gondii oocysts suspension in distilled water with the results of recovery from experimentally contaminated vegetables, in the case of vegetables samples, ten-fold loss of $T$. gondii oocysts was recorded. Furthermore, Escotte-Binet et al., (2019) proved the improvement of $T$. gondii oocysts recovery when using mechanical procedure for the lysis of oocysts' walls instead of alternate freeze-thaw cycles, since $T$. gondii oocysts possess very robust cell walls, as they underlined the interference of many parameters with the efficiency of oocysts recovery as the composition of analyzed matrices. Consequently, pretreatment and detection procedures should be adapted depending on the matrices.

While many studies have been conducted on the presence of other protozoan parasites (e.g., Giardia and Cryptosporidium) that have been incriminated in numerous foodborne outbreaks worldwide, only few studies have been reported on $T$. gondii in vegetables due to the lack of standardized methods for the investigation of this parasite in food matrices and the under-recognition of this mode of transmission for T. gondii. Another factor that have contributed to the paucity of surveillance studies on fresh produce was the low number of reported toxoplasmosis foodborne outbreaks, indeed, there have been only two outbreaks of toxoplasmosis associated with the consumption of fresh produce (Ekman et al., 2012) or juice (Morais et al., 2016), both reported in Brazil. Robertson, (2016) concluded that the rarity of reported toxoplasmosis associated with the consumption of salad vegetables could be due to the many potential routes of infection for this parasite and the fact that infections are often asymptomatic.

There is no doubt that the prevalence of $T$. gondii genotypes in the environment remains unknown (Lass et al., 2012), which is due, in part, to the low number of oocysts present in environmental samples. However, it is an important information for human health. Lass et al., (2012) have investigated the presence of $T$. gondii in 216 fresh produce samples collected in Poland and determined two genotypes: SAG2 type I (in six samples) and SAG2 type II (in two samples), which is surprising as type II was found to be the most prevalent genotype in human disease in Europe (mainly in France) (Ajzenberg et al., 2002).

\subsection{Prevalence of G. duodenalis}

Giardia duodenalis has been incriminated in numerous foodborne outbreaks. In the last one reported in El Salvador (Kasper et al., 2012), the consumption of local food prepared without proper monitoring has been 
suspected as a factor for this diarrheal illness. Besides, in 2016, Adam et al., (2016) have analyzed all the giardiasis outbreaks reported to the Centers for Disease Control and Prevention for 1971-2011, the 242 outbreaks affecting 41000 persons, resulted in 15.7\% from foodborne transmission. Otherwise, an expert elicitation study (Hald et al., 2016) estimated the proportion of cases of giardiasis caused by the foodborne route, it indicated that the importance of the foodborne route of infection was quite similar across regions (e.g., 0.11 in African Region; 0.13 in Eastern Mediterranean Region and 0.12 in European Region). Recently, numerous studies worldwide investigated the occurrence of Giardia duodenalis in fresh produce, using different elution procedures and detection methods based on immunofluorescence (Robertson and Gjerde, 2001a; Amoros et al., 2010; Utaaker et al., 2017), fast-stains (e.g., Lugol's iodine staining) (Ahmad et al., 2016; Amaechi et al., 2016; Mohamed et al., 2016; Alemu et al., 2019) and molecular assays (Utaaker et al., 2017). The contamination rates were variable, in leafy greens as lettuce; $61.5 \%$ was recorded in Spain (Amoros et al., 2010), 2\% in Norway (Robertson and Gjerde, 2001a), 2.7\% in Egypt (Ahmad et al., 2016), 0\% in India (Utaaker et al., 2015) and Southern Ethiopia (Alemu et al., 2019), while in parsley 0\% was reported in Norway (Robertson and Gjerde, 2001a), Iran (Shahnazi and Jafari-Sabet, 2010) and Turkey (Erdoğ rul and Şener, 2005), 25.5\% in Egypt (Eraky et al., 2014). Whereas in root vegetables as carrot, 14\% was reported in India (Utaaker et al., 2017), 4\% in North Central Nigeria (Amaechi et al., 2016) and 6.4\% in Southern Ethiopia (Alemu et al., 2019). The difference in contamination rates could be affected by multitude factors as detailed in section 3 bellow.

In parallel with the detection, the determination of genotypes is important to identify the source of contamination and the risk to human health. For Giardia, either humans or animals could be the source of contamination. The most frequent assemblages detected in humans are Assemblage A and B. The finding of Utaaker et al., (2017) revealed the presence of both Assemblages A and D in fresh produce (cucumber and tomato) sold in Chandigarh, in India. Assemblage D, which was found contaminating cucumber, indicates most likely a contamination from canine feces, and probably does not represent a risk to human health. Whereas Assemblage A, which was found contaminating tomatoes, is infectious to both humans and a range of other animals, and thus it is not possible to narrow down the likely source of contamination.

\subsection{Prevalence of Cryptosporidium spp.}

Cryptosporidium spp. is considered as one of the most important foodborne parasites. It is responsible for several well-documented foodborne outbreaks worldwide (Chalmers et al., 2019; Gharpure et al., 2019; Robertson et al., 2019) that were mainly associated with lettuce, pre-cut mixed salad leaves, apple cider, milk chicken salad and raw meat. The proportion of cryptosporidiosis outbreaks originated from food was higher in African Region (0.15) than other regions as European Region (0.10) or Western Pacific Region (0.10), as estimated by Hald et al., (2016).

Fresh produce that is consumed after minimal preparation is most likely a vehicle for the transmission of Cryptosporidium infection (Amoros et al., 2010). Therefore, several studies investigated the presence of Cryptosporidium in fresh produce based on molecular or immunofluorescent assays, as well as acid-fast stains (e.g., modified Ziehl-Neelsen staining) that are commonly used (Table 1). The contamination of leafy greens as lettuce was low in Canada (0\%) (Lalonde and Gajadhar, 2016b) and India (0\%) (Utaaker et al., 2017), compared to that reported in African regions as Egypt (43.3\%) (El Said Said, 2012) and (26.3\%) (El Sherbini et al., 2016). Similarly for root vegetables as that ranged from $(0 \%)$ in India (Utaaker et al., 2017) to (33.3\%) in Seoul (Korea). The distribution of parasites in fresh produce could be affected by numerous factors (see section 3). 
Unlike microscopic assays that are unable to identify the infectious Cryptosporidium species, molecular analyses allow the determination of species and genotypes that may provide information on the sources of contamination, particularly whether the parasites are likely to be from humans (Cryptosporidium hominis) or animals (generally C. parvum). Rzezutka et al., (2010); Hong et al., (2014); Lalonde and Gajadhar, (2016b) and Utaaker et al., (2017) reported that DNA isolated from vegetable samples positive for Cryptosporidium belong to C. parvum, the source of contamination of fresh produce could thus be from either dirty hands or infected livestock or other animals.

\section{Factors affecting the prevalence of parasitic contamination of vegetables:}

The variation of the parasitic prevalence reported among the different studies could be related to multiple factors, these were: i) the processing procedures of analyzed vegetables, ii) the climatic conditions, iii) the geographic location, iv) the vegetable type, v) the quality of irrigation water and fertilizers, and vi) the source of vegetables.

\subsection{Processing procedures}

As detailed in section 1, there are various methods to analyze fresh vegetable samples for the presence of protozoan parasites, these methods showed variable sensitivity, efficiency and detection limits as demonstrated by several authors. Alongside these studies, Duedu et al., (2014) evaluated the effect of three elution buffers namely tap water, PBS and saline $(0.85 \%)$ on the recovery of Cryptosporidium and Giardia, saline was the most effective and recovered (52\%) of parasites followed by PBS (34\%) and tap water (14\%). There was however some correlations between the methods used and the type of parasite recovered, Cryptosporidium was the most parasite recovered in saline whereas others as S. stercoralis recovered most from PBS. Concordantly, Al-Binali et al., (2006) demonstrated that the use of Tris-buffer-saline for the extraction of Cryptosporidium, Giardia and other parasites, significantly increased the isolation rate (27.2\%) of the parasites compared with the use of tap water (7.8\%). Furthermore, Robertson and Gjerde, (2001b) evaluated factors affecting the recovery of both Cryptosporidium oocysts and Giardia cysts from vegetable produce (lettuce). These were: (i) sample weight, (ii) contribution of elution procedure to losses, (iii) IMS kit used, and (iv) strength of magnet during IMS. The evaluation indicated that the differences in sample weight $(30 \mathrm{~g}$ and $100 \mathrm{~g})$, rather than elution technique, IMS kit or magnet strength were responsible for the increase of (oo)cysts recovery. This later may be related to several factors, namely lighter samples required the use of smaller volumes of elution buffer which may reduce the potential for losses during manipulation and centrifugation. In addition, lighter samples required less space in the bag for washing that provided more contact space between elution buffer and samples. On another hand, Macarisin et al., (2010) demonstrated that Cryptosporidium oocysts were capable of strongly adhering to spinach plants after contact with contaminated water and were also internalized within the leaves, that made this pathogen resist to washing. Hence samples processing using an effective elution method may result in preventing a better recovery of oocysts internalized in vegetable leaves.

Otherwise, Robertson and Gjerde, (2000) proved that both the washing procedure and the subsequent separation by IMS will have contributed to the improved recovery efficiencies of Giardia and Cryptosporidium. The IMS provides improvement by selecting the parasites from the other debris present in the concentrate. In addition, Lass et al., (2012) underlined the contribution of the DNA extraction step to the improvement of T. gondii oocysts recovery, accordingly, the reported rates of $T$ gondii in vegetables could be underestimated, because of the resistance of oocyst wall resulting in difficult $T$. gondii DNA extraction. Moreover, PCR inhibitors such as 
humid acids or polysaccharides play a role in environmental samples. They may reduce the PCR sensitivity by up to $100-1,000$ times.

\subsection{Climatic conditions}

The distribution of parasitic contamination could be influenced by seasonal changes. Indeed, Daryani et al., (2008); Al-Megrm, (2010) and Fallah et al., (2012) revealed that the rate of contamination was significantly higher in warm seasons than in cold ones, which may be related to the frequent use of untreated wastewater for irrigation of vegetables during spring and summer resulting in higher rate of parasitic contamination in these seasons. However, Charron et al., (2004) correlated the presence of parasites to both drought and rainy periods since the increases in precipitation could intensify erosion leading to potential parasitic contamination of surface and groundwater, and decrease the effectiveness of water treatment. As the heavy rain following drought could lead to more severe runoff and risk of water contamination.

The climate could also affect (oo)cysts lifetime. In fact, Amahmid et al., (1999) reported that after contamination induced by irrigation with sewage, three days were sufficient for the apparent disappearance of Giardia cysts. This decrease in the burden of Giardia cysts can be related to high temperatures and intense solar radiation, which would favor the desiccation of cysts. Indeed, factors as solar radiation, temperature, humidity and rainfall directly affect the persistence of microorganisms (Larkin et al., 1978). Concordantly, Lélu et al., (2012) proved that drought affect the survival of $T$. gondii oocysts as the proportion of oocysts surviving in soil after 100 days was $7,4 \%$ in dry conditions (281 mm of precipitation per year) and 43,7\% in damp conditions (3648 $\mathrm{mm}$ of precipitation per year).

\subsection{Geographic location}

The geographic location reflects, in part, the levels of development and application of hygiene practices in regions/countries. For instance, Utaaker et al., (2017) investigated the presence of parasites in vegetables sold in Chandigarh which is generally regarded as one of the cleanest cities in India, vegetables were contaminated by protozoan parasites, with $6 \%$ contaminated with Cryptosporidium oocysts and 5\% with Giardia cysts. Studies from some other low- or middle-income countries where hygiene, sanitation and water quality may be suboptimal (Dixon, 2016) have indicated similar or higher levels of contamination (El Said Said, 2012; Maikai et al., 2013). In more developed countries, the rate of contaminated vegetables with these parasites tends to be lower (Robertson and Gjerde, 2001a; Rzezutka et al., 2010; Lalonde and Gajadhar, 2016b).

\subsection{Vegetables types}

The structure of vegetables was largely involved in the level of parasitic contamination. El Said Said, (2012); Duedu et al., (2014); Istifanus and Panda, (2018) reported that leafy greens as lettuce, cabbage and rocket were more susceptible for contamination compared to other vegetables with smooth surfaces, due to their curly leaves that may increase the attachment of parasites as Cryptosporidium and Giardia. In addition, Amahmid et al., (1999) found that leafy greens as coriander and mint were relatively more contaminated with Giardia compared to carrots and radish, which could be related to their dense foliage offering a large contamination surface. Contrarily to Sleman Ali et al., (2018) who showed that contamination rates of Cryptosporidium were not significantly related to vegetable type, which is similar to the results of Maikai et al., (2013) and Rahman et al., (2014) who found no difference between contamination rates of Cryptosporidium in different types of vegetables.

\subsection{Quality of irrigation water and fertilizers}


The quality of irrigation water was usually incriminated in the presence of waterborne parasites in fresh produce. Indeed, several studies found that the use of raw water in irrigation leads to contamination of vegetables with $G$. duodenalis (Amahmid et al., 1999; Daryani et al., 2008; Abougrain et al., 2010; Amoros et al., 2010; Shahnazi and Jafari-Sabet, 2010), and Cryptosporidium (Sleman Ali et al., 2018), or both parasites (Amoros et al., 2010). Another factor contributing to the contamination of crops with Cryptosporidium is the fertilization using manure from cattle and sheep, containing viable oocysts of Cryptosporidium (Moore et al., 2007; Rzezutka et al., 2010; Sleman Ali et al., 2018), since oocysts can remain viable in manure for several months (Bukhari, 1995), and in soil for several weeks especially at low temperature (Nasser et al., 2007).

\subsection{Vegetables source}

In the reviewed studies, some have tested vegetables samples from different sources to investigate the effect of this parameter on parasitic contamination. Duedu et al., (2014) revealed a very low prevalence of parasites in vegetables obtained within the supermarkets and this was about ten times more among vegetables obtained from the open-aired markets. Moreover, Alemu et al., (2019) found that vegetables directly supplied by farmers to vendors were 3.5 times more likely to be contaminated with parasites as compared to vegetables supplied by large scale vendors. Noting that large scale vendors in the study area used appropriate vehicles for the distribution of vegetables, while small scale vendors were supplied directly by farmers via back of animals or human labor, which exposed vegetables to contamination. Furthermore, Lass et al., (2012) proved that the cultivation of vegetables in farms where the contact with feline feces is more probable increase the risk of contamination with T. gondii. Contrarily, Hassan et al., (2012); Omowaye and Audu, (2012) showed no difference between the contamination rates found at the various markets, this could be explained, in part, by the various sources from which vegetables are brought to these markets.

\section{Conclusion}

T. gondii, G. duodenalis and Cryptosporidium spp. are considered as pathogens in human and are frequently present in the environment leading to the contamination of fresh vegetables worldwide. These matrices are potentially contaminated by protozoan and could represent a health risk for populations. Existing studies are heterogeneous supporting the need for further investigation of standardized methods

In this review, we underline the importance of the determination of (oo) cysts recovery efficiency and detection limits (LOD) to validate the methods for monitoring protozoan parasites. These standardized methods will enable us to compare the efficiency and sensitivity between methods as well as the prevalence of resistance forms between the different regions.

Acknowledgments. The authors are grateful to Nikki Sabourin-Gibbs, Rouen University Hospital, for her help in editing the manuscript.

Financial support. Financial support was granted by CAMPUS FRANCE (PHC TOUBKAL 2018 (FrenchMorocco bilateral program) Grant Number: 38970PE.

Conflict of interest. The authors declare that there is no conflict of interest.

Ethical standards. Not applicable 


\section{References}

Abougrain, A. K., Nahaisi, M. H., Madi, N. S., Saied, M. M. and Ghenghesh, K. S. (2010). Parasitological contamination in salad vegetables in Tripoli-Libya. Food Control 21, 760-762. doi: 10.1016/j.foodcont.2009.11.005.

Adam, E. A., Yoder, J. S., Gould, L. H., Hlavsa, M. C. and Gargano, J. W. (2016). Giardiasis outbreaks in the United States, 1971-2011. Epidemiology and Infection 144, 2790-2801. doi: $10.1017 / \mathrm{S} 0950268815003040$.

Ahmad, S. O., El Fadaly, H. A., Zaki, M. S. and Barakat, A. M. A. (2016). Incidence of zoonotic parasites in egyptian raw vegetable salads. 13, 27-31. doi: 10.7537/marslsj13021605.Key.

Ahmed, S. A. and Karanis, P. (2018). An overview of methods/techniques for the detection of Cryptosporidium in food samples. Parasitology Research 117, 629-653. doi: 10.1007/s00436-017-5735-0.

Ajzenberg, D., Cogné, N., Paris, L., Bessières, M., Thulliez, P., Filisetti, D., Pelloux, H., Marty, P. and Dardé, M. (2002). Genotype of 86 Toxoplasma gondii Isolates Associated with Human Congenital Toxoplasmosis, and Correlation with Clinical Findings . The Journal of Infectious Diseases 186, 684-689. doi: $10.1086 / 342663$.

Al-Binali, A. M., Bello, C. S., El-Shewy, K. and Abdulla, S. E. (2006). The prevalence of parasites in commonly used leafy vegetables in South Western Saudi Arabia. Saudi Medical Journal 27, 613-616.

Al-Megrm, W. A. . (2010). Prevalence of intestinal parasites in leafy vegetables in Riyadh, Saudi Arabia. International Journal of Tropical Medicine 5, 20-23.

Alemu, G., Mama, M., Misker, D. and Haftu, D. (2019). Parasitic contamination of vegetables marketed in Arba Minch town, southern Ethiopia. BMC Infectious Diseases 19, 1-7. doi: 10.1186/s12879-019-4020-5.

Alhabbal, A. T. (2015). The prevalence of parasitic contamination on common sold vegetables in Alqalamoun region. International Journal of Pharmaceutical Sciences Review and Research 30, 94-97.

Ali, M. A., Al-Herrawy, A. Z. and El-Hawaary, S. E. (2004). Detection of enteric viruses, Giardia and Cryptosporidium in two different types of drinking water treatment facilities. Water Research 38, 39313939. doi: 10.1016/j.watres.2004.06.014.

Amaechi, E. ., Ohaeri, C. ., Ukpai, O. . and Adegbite, R. A. (2016). Prevalence of Parasitic contamination of salad vegetables in Ilorin, North Central, Nigeria. Momona Ethiopian Journal of Science 8, 136-145. doi: 10.4314/mejs.v8i2.3

Amahmid, O., Asmama, S. and Bouhoum, K. (1999). The effect of waste water reuse in irrigation on the contamination level of food crops by Giardia cysts and Ascaris eggs. International Journal of Food Microbiology 49, 19-26. doi: 10.1016/S0168-1605(99)00058-6.

Amoros, I., Alonso, J. L. and Cuesta, G. (2010). Cryptosporidium Oocysts and Giardia Cysts on Salad Products Irrigated with Contaminated Water. Journal of Food Protection 73, 1138-1140. doi: 10.4315/0362-028x-73.6.1138.

Avazpoor, M., Yousefipoor, M., Dusty, M., Mehdipour, M., Seifipour, F. and Gholam, Z. (2015). Determination of the level of parasitic infection (Cryptosporidium and Giardia) of the vegetables marketed in Ilam city. Environmental Health Engineering and Management Journal 2, 37-40.

Bailenger, J. (1962). Valeur comparée des méthodes d'enrichissement en coprologie parasitaire. Le Pharmacien Biologiste 3, 249-259. 
Benti, G. and Gemechu, F. (2014). Parasitic contamination on vegetables irrigated with awash river in selected farms, Eastern Showa, Ethiopia. Journal of Parasitology and Vector Biology 5, 103-109. doi: 10.5897/JPVB2014.0150.

Bethea, D. A. (2014). Detection of Toxoplasma gondii in fresh produce. Master of Science, University of Georgia.

Bukhari, Z. (1995). Cryptosporidium infections in livestock and the significance of environmental contamination with oocysts.

Calvo, M., Carazo, M., Arias, M. L., Chaves, C., Monge, R. and Chinchilla, M. (2004). Prevalence of Cyclospora sp., Cryptosporidium sp, microsporidia and fecal coliform determination in fresh fruit and vegetables consumed in Costa Rica]. Archivos latinoamericanos de nutricion 54, 428-432.

Chalmers, R. M., Robinson, G., Elwin, K. and Elson, R. (2019). Analysis of the Cryptosporidium spp. and gp60 subtypes linked to human outbreaks of cryptosporidiosis in England and Wales, 2009 to 2017. Parasites and Vectors 12, 1-13. doi: 10.1186/s13071-019-3354-6.

Charron, D. F., Thomas, M. K., Waltner-Toews, D., Aramini, J. J., Edge, T., Kent, R. A., Maarouf, A. R. and Wilson, J. (2004). Vulnerability of waterborne diseases to climate change in Canada: A review. Journal of Toxicology and Environmental Health - Part A 67, 1667-1677. doi: 10.1080/15287390490492313.

Cook, N., Paton, C. A., Wilkinson, N., Nichols, R. A. B., Barker, K. and Smith, H. V. (2006). Towards standard methods for the detection of Cryptosporidium parvum on lettuce and raspberries. Part 1: Development and optimization of methods. International Journal of Food Microbiology 109, $215-221$. doi: 10.1016/j.ijfoodmicro.2005.12.015.

Daryani, A., Ettehad, G. H., Sharif, M., Ghorbani, L. and Ziaei, H. (2008). Prevalence of intestinal parasites in vegetables consumed in Ardabil, Iran. Food Control 19, 790-794. doi: 10.1016/j.foodcont.2007.08.004.

Dixon, B. R. (2016). Parasitic illnesses associated with the consumption of fresh produce - an emerging issue in developed countries. Current Opinion in Food Science 8, 104-109. doi: 10.1016/j.cofs.2016.04.009.

Duedu, K. O., Yarnie, E. A., Tetteh-Quarcoo, P. B., Attah, S. K., Donkor, E. S. and Ayeh-Kumi, P. F. (2014). A comparative survey of the prevalence of human parasites found in fresh vegetables sold in supermarkets and open-aired markets in Accra, Ghana. BMC Research Notes 7, 1-6. doi: 10.1186/17560500-7-836.

Dumètre, A. and Dardé, M. L. (2005). Immunomagnetic separation of Toxoplasma gondii oocysts using a monoclonal antibody directed against the oocyst wall. Journal of Microbiological Methods 61, $209-217$. doi: 10.1016/j.mimet.2004.11.024.

Ekman, C. C. J., Chiossi, M. F. do V., Meireles, L. R., de Andrade, H. F., Figueiredo, W. M., Marciano, M. A. M. and Luna, E. J. de A. (2012). Case-control study of an outbreak of acute toxoplasmosis in an industrial plant in the state of São Paulo, Brazil. Revista do Instituto de Medicina Tropical de Sao Paulo 54, 239-244. doi: 10.1590/S0036-46652012000500001.

El Said Said, D. (2012). Detection of parasites in commonly consumed raw vegetables. Alexandria Journal of Medicine 48, 345-352. doi: 10.1016/j.ajme.2012.05.005.

El Sherbini, G. T., Hany Kamel, N. O., Geneedy, M. R. and Temsah, A. G. (2016). A comparative study of the occurrence of Cryptosporidium parvum oocysts found on fresh fruits and vegetables sold in 
supermarkets and open-aired markets. International Journal of Current Microbiology and Applied Sciences 5, 760-768. doi: 10.20546/ijcmas.2016.508.085.

Eraky, M. A., Rashed, S. M., Nasr, M. E. S., El-Hamshary, A. M. S. and Salah El-Ghannam, A. (2014). Parasitic contamination of commonly consumed fresh leafy vegetables in Benha, Egypt. Journal of Parasitology Research 2014,. doi: 10.1155/2014/613960.

Erdoğ rul, Ö. and Şener, H. (2005). The contamination of various fruit and vegetable with Enterobius vermicularis, Ascaris eggs, Entamoeba histolyca cysts and Giardia cysts. Food Control 16, 559-562. doi: 10.1016/j.foodcont.2004.06.016.

Escotte-Binet, S., Da Silva, A. M., Cancès, B., Aubert, D., Dubey, J., La Carbona, S., Villena, I. and Poulle, M. L. (2019). A rapid and sensitive method to detect Toxoplasma gondii oocysts in soil samples. Veterinary Parasitology 274, 108904. doi: 10.1016/j.vetpar.2019.07.012.

Ezatpour, B., Chegeni, A. S., Abdollahpour, F., Aazami, M. and Alirezaei, M. (2013). Prevalence of parasitic contamination of raw vegetables in Khorramabad, Iran. Food Control 34, 92-95. doi: 10.1016/j.foodcont.2013.03.034.

Fallah, A. A., Pirali-Kheirabadi, K., Shirvani, F. and Saei-Dehkordi, S. S. (2012). Prevalence of parasitic contamination in vegetables used for raw consumption in Shahrekord, Iran: Influence of season and washing procedure. Food Control 25, 617-620. doi: 10.1016/j.foodcont.2011.12.004.

Fallah, A. A., Makhtumi, Y. and Pirali-Kheirabadi, K. (2016). Seasonal study of parasitic contamination in fresh salad vegetables marketed in Shahrekord, Iran. Food Control 60, 538-542. doi: 10.1016/j.foodcont.2015.08.042.

FAO/WHO (Food and Agriculture Organization of the United Nations and World Health Organization) (2012). Multicriteria-Based Ranking for Risk Management of Food-Borne Parasites.

Gabre, R. M. and Shakir, A. (2016). Prevalence of some human enteroparasites in commonly consumed raw vegetables in Tabuk, Saudi Arabia. Journal of Food Protection 79, 655-658. doi: 10.4315/0362028X.JFP-15-485.

Ganz, K. R., Clime, L., Farber, J. M., Corneau, N., Veres, T. and Dixon, B. R. (2015). Enhancing the detection of Giardia duodenalis cysts in foods by inertial microfluidic separation. Applied and Environmental Microbiology 81, 3925-3933. doi: 10.1128/AEM.03868-14.

Gharpure, R., Perez, A., Miller, A. D., Wikswo, M. E., Silver, R. and Hlavsa, M. C. (2019). Cryptosporidiosis outbreaks - United states, 2009-2017. Morbidity and Mortality Weekly Report 68, 568572. doi: 10.15585/mmwr.mm6825a3.

Hald, T., Aspinall, W., Devleesschauwer, B., Cooke, R., Corrigan, T., Havelaar, A. H., Gibb, H. J., Torgerson, P. R., Kirk, M. D., Angulo, F. J., Lake, R. J., Speybroeck, N. and Hoffmann, S. (2016). World Health Organization estimates of the relative contributions of food to the burden of disease due to selected foodborne hazards: A structured expert elicitation. PLoS ONE 11, 1-35. doi: 10.1371/journal.pone.0145839.

Hassan, A., Farouk, H. and Abdul-Ghani, R. (2012). Parasitological contamination of freshly eaten vegetables collected from local markets in Alexandria, Egypt: A preliminary study. Food Control 26, 500-503. doi: 10.1016/j.foodcont.2012.01.033.

Hohweyer, J., Cazeaux, C., Travaillé, E., Languet, E., Dumètre, A., Aubert, D., Terryn, C., Dubey, J. P., 
Azas, N., Houssin, M., Loïc, F., Villena, I. and La Carbona, S. (2016). Simultaneous detection of the protozoan parasites Toxoplasma, Cryptosporidium and Giardia in food matrices and their persistence on basil leaves. Food Microbiology 57, 36-44. doi: 10.1016/j.fm.2016.01.002.

Hong, S., Kim, K., Yoon, S., Park, W. Y., Sim, S. and Yu, J. R. (2014). Detection of Cryptosporidium parvum in environmental soil and vegetables. Journal of Korean medical science 29, 1367-1371. doi: 10.3346/jkms.2014.29.10.1367.

Ismail, Y. (2016). Prevalence of parasitic contamination in salad vegetables collected from supermarkets and street vendors in Amman and Baqa'a - Jordan. Polish Journal of Microbiology 65, 201-207. doi: 10.5604/17331331.1204480.

ISO 18744. (2016). Microbiology of the food chain - Detection and enumeration of Cryptosporidium and Giardia in fresh leafy green vegetables and berry fruits.

Istifanus, W. A. and Panda, S. M. (2018). Parasitic agents in fresh fruits and vegetables sold in open markets in Bauchi, Nigeria. Journal of Food Quality and Hazards Control 5, 84-88. doi: 10.29252/jfqhc.5.3.84.

Kasper, M. R., Lescano, A. G., Lucas, C., Gilles, D., Biese, B. J., Stolovitz, G. and Reaves, E. J. (2012). Diarrhea outbreak during U.S. military training in El Salvador. PLOS ONE 7, 1-8. doi: 10.1371/journal.pone.0040404.

Keserue, H. A., Füchslin, H. P., Wittwer, M., Nguyen-Viet, H., Nguyen, T. T., Surinkul, N., Koottatep, T., Schürch, N. and Egli, T. (2012). Comparison of rapid methods for detection of Giardia spp. and Cryptosporidium spp. (Oo)cysts using transportable instrumentation in a field deployment. Environmental Science and Technology 46, 8952-8959. doi: 10.1021/es301974m.

Kumar, T., Onichandran, S., Lim, Y. A. L., Sawangjaroen, N., Ithoi, I., Andiappan, H., Salibay, C. C., Dungca, J. Z., Chye, T. T., Sulaiman, W. Y. W., Lau, Y. L. and Nissapatorn, V. (2014). Comparative study on waterborne parasites between Malaysia and Thailand: A new insight. American Journal of Tropical Medicine and Hygiene 90, 682-689. doi: 10.4269/ajtmh.13-0266.

Lalle, M., Possenti, A., Dubey, J. P. and Pozio, E. (2018). Loop-Mediated Isothermal Amplification-LateralFlow Dipstick (LAMP-LFD) to detect Toxoplasma gondii oocyst in ready-to-eat salad. Food Microbiology 70, 137-142. doi: 10.1016/j.fm.2017.10.001.

Lalonde, L. F. and Gajadhar, A. A. (2016a). Optimization and validation of methods for isolation and realtime PCR identification of protozoan oocysts on leafy green vegetables and berry fruits. Food and Waterborne Parasitology 2, 1-7. doi: 10.1016/j.fawpar.2015.12.002.

Lalonde, L. F. and Gajadhar, A. A. (2016b). Detection of Cyclospora cayetanensis, Cryptosporidium spp., and Toxoplasma gondii on imported leafy green vegetables in Canadian survey. Food and Waterborne Parasitology 2, 8-14. doi: 10.1016/j.fawpar.2016.01.001.

Larkin, E. P., Tierney, J. T., Lovett, J., Van Donsel, D., Francis, D. W. and Jackson, G. J. (1978). Land application of sewage wastes: potential for contamination of foodstuffs and agricultural soils by viruses, bacterial pathogens and parasites. State of knowledge in land treatment of wastewater 2, 215-223.

Lass, A., Pietkiewicz, H., Szostakowska, B. and Myjak, P. (2012). The first detection of Toxoplasma gondii DNA in environmental fruits and vegetables samples. European Journal of Clinical Microbiology and Infectious Diseases 31, 1101-1108. doi: 10.1007/s10096-011-1414-8.

Le Quynh Chau, H., Thong, H. T., Chao, N. Van, Pham Hoang Son Hung, V. V. H., An, L. Van, Fujieda, A., Ueru, T. and Akamatsu, M. (2014). Microbial and Parasitic Contamination on Fresh Vegetables Sold 
in Traditional Markets in Hue City, Vietnam. Journal of Food and Nutrition Research 2, 959-964. doi: 10.12691/jfnr-2-12-16.

Lélu, M., Villena, I., Dardé, M. L., Aubert, D., Geers, R., Dupuis, E., Marnef, F., Poulle, M. L., Gotteland, C., Dumètre, A. and Gilot-Fromonta, E. (2012). Quantitative estimation of the viability of Toxoplasma gondii oocysts in soil. Applied and Environmental Microbiology 78, 5127-5132. doi: 10.1128/AEM.00246-12.

Losio, M. N., Pavoni, E., Bilei, S., Bertasi, B., Bove, D., Capuano, F., Farneti, S., Blasi, G., Comin, D., Cardamone, C., Decastelli, L., Delibato, E., De Santis, P., Di Pasquale, S., Gattuso, A., Goffredo, E., Fadda, A., Pisanu, M. and De Medici, D. (2015). Microbiological survey of raw and ready-to-eat leafy green vegetables marketed in Italy. International Journal of Food Microbiology 210, 88-91. doi: 10.1016/j.ijfoodmicro.2015.05.026.

Macarisin, D., Bauchan, G. and Fayer, R. (2010). Spinacia oleracea L. leaf stomata harboring Cryptosporidium parvum oocysts: A potential threat to food safety. Applied and Environmental Microbiology 76, 555-559. doi: 10.1128/AEM.02118-09.

Maikai, B. V., Elisha, I. A. and Baba-Onoja, E. B. T. (2012). Contamination of vegetables sold in markets with helminth eggs in Zaria metropolis, Kaduna State, Nigeria. Food Control 28, 345-348. doi: 10.1016/j.foodcont.2012.05.035.

Maikai, B. V., Baba-Onoja, E. B. T. and Elisha, I. A. (2013). Contamination of raw vegetables with Cryptosporidium oocysts in markets within Zaria metropolis, Kaduna State, Nigeria. Food Control 31, 4548. doi: 10.1016/j.foodcont.2012.09.032.

Marchioro, A. A., Tiyo, B. T., Colli, C. M., De Souza, C. Z., Garcia, J. L., Gomes, M. L. and FalavignaGuilherme, A. L. (2016). First Detection of Toxoplasma gondii DNA in the Fresh Leafs of Vegetables in South America. Vector-Borne and Zoonotic Diseases 16, 624-626. doi: 10.1089/vbz.2015.1937.

Miller, W. A., Gardner, I. A., Atwill, E. R., Leutenegger, C. M., Miller, M. A., Hedrick, R. P., Melli, A. C., Barnes, N. M. and Conrad, P. A. (2006). Evaluation of methods for improved detection of Cryptosporidium spp. in mussels (Mytilus californianus). Journal of Microbiological Methods 65, 367379. doi: 10.1016/j.mimet.2005.08.011.

Mohamed, M. A., Siddig, E. E., Elaagip, A. H., Edris, A. M. M. and Nasr, A. A. (2016). Parasitic contamination of fresh vegetables sold at central markets in Khartoum state, Sudan. Annals of Clinical Microbiology and Antimicrobials 15, 5-11. doi: 10.1186/s12941-016-0133-5.

Moore, J. E., Millar, B. C., Kenny, F., Lowery, C. J., Xiao, L., Rao, J. R., Nicholson, V., Watabe, M., Heaney, N., Sunnotel, O., McCorry, K., Rooney, P. J., Snelling, W. J. and Dooley, J. S. G. (2007). Detection of Cryptosporidium parvum in lettuce. International Journal of Food Science and Technology 42, 385-393. doi: 10.1111/j.1365-2621.2006.01235.x.

Morais, R. dos A. P. B., Freire, A. B. C., Barbosa, D. R. L., Silva, L. de C. T. da, Pinheiro, A. F., Costa, S. S. da, Ramos, F. L. de P., Bichara, C. N. C., Lima, L. J. B. and Silva, A. V. da (2016). Surto de toxoplasmose aguda no Município de Ponta de Pedras, Arquipélago do Marajó, Estado do Pará, Brasil: características clínicas, laboratoriais e epidemiológicas.

Nasser, A. M., Tweto, E. and Nitzan, Y. (2007). Die-off of Cryptosporidium parvum in soil and wastewater effluents. Journal of Applied Microbiology 102, 169-176. doi: 10.1111/j.1365-2672.2006.03048.x. 
Nazemi, S., Raei, M., Amiri, M. and Chaman, R. (2012). Parasitic Contamination of Raw Vegetables in Shahroud, Semnan. Zahedan Journal of Research in Medical Sciences 14, 84-86.

Olyaei, A. and Hajivandi, L. (2013). Parasitological contamination of markets and farms in vegetables consumed in Southern Iran. Global Veterinaria 10, 327-331. doi: 10.5829/idosi.gv.2013.10.3.71185.

Omowaye, O. and Audu, P. (2012). Incidence and detection of parasitic infections by cyst and ova on fruits and vegetables from different major markets in Kogi, Nigeria. Journal of Applied and Natural Science 42-46.

Ortega, Y. R. and Sanchez, R. (2010). Update on Cyclospora cayetanensis, a food-borne and waterborne parasite. Clinical Microbiology Reviews 23, 218-234. doi: 10.1128/CMR.00026-09.

Pomares, C., Ajzenberg, D., Bornard, L., Bernardin, G., Hasseine, L., Darde, M.-L. and Marty, P. (2011). Toxoplasmosis and horse meat, France. Emerging infectious diseases 17, 1327-1328. doi: 10.3201/eid1707.101642.

Rahman, M. J., Islam Talukder, M. A., Hossain, M. F., Mahomud, M. S., Atikul Islam, M. and Shamsuzzoha, M. (2014). Detection of Cryptosporidium oocyts in commonly consumed fresh salad vegetables. American Journal of Microbiological Research 2, 224-226. doi:10.12691/ajmr-2-6-9.

Ramirez-Martinez, M. L., Olmos-Ortiz, L. M., Barajas-Mendiola, M. A., Giono Cerezo, S., Avila, E. E. and Cuellar-Mata, P. (2015). A PCR procedure for the detection of Giardia intestinalis cysts and Escherichia coli in lettuce. Letters in Applied Microbiology 60, 517-523. doi: 10.1111/lam.12402.

Ranjbar-Bahadori, S., Mostoophi, A. and Shemshadi, B. (2013). Study on Cryptosporidium contamination in vegetable farms around Tehran. Tropical Biomedicine 30, 193-198.

Robertson, L. J. (2016). Parasitic protozoa in salad vegetables. Elsevier Inc. doi: 10.1016/B978-0-12-8019160.00005-4.

Robertson, L. J. and Gjerde, B. (2000). Isolation and enumeration of Giardia cysts, Cryptosporidium oocysts, and Ascaris eggs from fruits and vegetables. Journal of food protection 63, 775-778. doi: 10.4315/0362028X-63.6.775.

Robertson, L. J. and Gjerde, B. (2001a). Occurrence of parasites on fruits and vegetables in Norway. Journal of food protection 64, 1793-1798. doi: 10.4315/0362-028X-64.11.1793.

Robertson, L. J. and Gjerde, B. (2001b). Factors affecting recovery efficiency in isolation of Cryptosporidium oocysts and Giardia cysts from vegetables for standard method development. Journal of Food Protection 64, 1799-1805. doi: 10.4315/0362-028X-64.11.1799.

Robertson, L. J., Sprong, H., Ortega, Y. R., van der Giessen, J. W. B. and Fayer, R. (2014). Impacts of globalisation on foodborne parasites. Trends in Parasitology 30, 37-52. doi: 10.1016/j.pt.2013.09.005.

Robertson, L. J., Temesgen, T. T., Tysnes, K. R. and Eikås, J. E. (2019). An apple a day: An outbreak of cryptosporidiosis in Norway associated with self-pressed apple juice. Epidemiology and Infection 147, 2527. doi: $10.1017 / \mathrm{S} 0950268819000232$.

Rzezutka, A., Nichols, R. A. B., Connelly, L., Kaupke, A., Kozyra, I., Cook, N., Birrell, S. and Smith, H. V. (2010). Cryptosporidium oocysts on fresh produce from areas of high livestock production in Poland. International Journal of Food Microbiology 139, 96-101. doi: 10.1016/j.ijfoodmicro.2010.01.027.

Saida, L. A. and Nooraldeen, K. N. (2014). Prevalence of parasitic stages in six leafy vegetables in markets of Erbil City, Kurdistan Region-Iraq. Zanco Journal of Pure and Applied Sciences 26, 25-30.

Saki, J., Asadpoori, R. and Khademvatan, S. (2013). Prevalence of intestinal parasites in vegetables 
consumed in Ahvaz, South West of Iran. Journal of Medical Sciences (Faisalabad) 13, 488-492. doi: 10.3923/jms.2013.488.492.

Shahnazi, M. and Jafari-Sabet, M. (2010). Prevalence of parasitic contamination of raw vegetables in villages of Qazvin Province, Iran. Foodborne Pathog Dis 7, 1025-1030. doi: 10.1089/fpd.2009.0477.

Shapiro, K., Kim, M., Rajal, V. B., Arrowood, M. J., Packham, A., Aguilar, B. and Wuertz, S. (2019). Simultaneous detection of four protozoan parasites on leafy greens using a novel multiplex PCR assay. Food Microbiology 84, 103252. doi: 10.1016/j.fm.2019.103252.

Shields, J. M., Lee, M. M. and Murphy, H. R. (2012). Use of a common laboratory glassware detergent improves recovery of Cryptosporidium parvum and Cyclospora cayetanensis from lettuce, herbs and raspberries. International Journal of Food Microbiology 153, 123-128. doi: 10.1016/j.ijfoodmicro.2011.10.025.

Simon-Oke, I. A., Afolabi, O. J. and Obasola, O. P. (2014). Parasitic contamination of fruits and vegetables sold at Akure Metropolis, Ondo State, Nigeria. 6, 30-35.

Siyadatpanah, A., Tabatabaei, F., Zeydi, A. E., Spotin, A., Fallah-Omrani, V., Assadi, M., Moradi, S., Rostami, A., Memari, F. and Hajialiani, F. (2013). Parasitic contamination of raw vegetables in Amol, North of Iran. Archives of Clinical Infectious Diseases 8,. doi: 10.5812/archeid.15983.

Sleman Ali, H., Mageed, S. N., Khaniki, G. R. J., Shariatifar, N., Yunesian, M., Rezaeian, M. and Saleh, K. (2018). Contamination of Cryptosporidium spp. oocysts in raw vegetables produced in Koya City, Iraq. Journal of Food Quality and Hazards Control 5, 89-93. doi: 10.29252/jfqhc.5.3.89.

Tefera, T., Biruksew, A., Mekonnen, Z. and Eshetu, T. (2014). Parasitic contamination of fruits and vegetables collected from selected local markets of Jimma Town, Southwest Ethiopia. International Scholarly Research Notices 2014, 1-7. doi: 10.1155/2014/382715.

Umeche, N. (1991). Parasite ova and cysts in fruits in Calabar, Nigeria. The Nigeria Journal of Parasit 12, 8587.

Utaaker, K. S., Huang, Q. and Robertson, L. J. (2015). A reduced-cost approach for analyzing fresh produce for contamination with Cryptosporidium oocysts and/or Giardia cysts. Food Research International 77, 326-332. doi: 10.1016/j.foodres.2015.05.010.

Utaaker, K. S., Kumar, A., Joshi, H., Chaudhary, S. and Robertson, L. J. (2017). Checking the detail in retail: Occurrence of Cryptosporidium and Giardia on vegetables sold across different counters in Chandigarh, India. International Journal of Food Microbiology 263, 1-8. doi: 10.1016/j.ijfoodmicro.2017.09.020. 
Table 1: Methods used for monitoring T. gondii, G. duodenalis and Cryptosporidium spp. in fresh vegetables (lettuce, parsley, coriander, radish, and carrot), and the prevalence of these parasites according to different studies

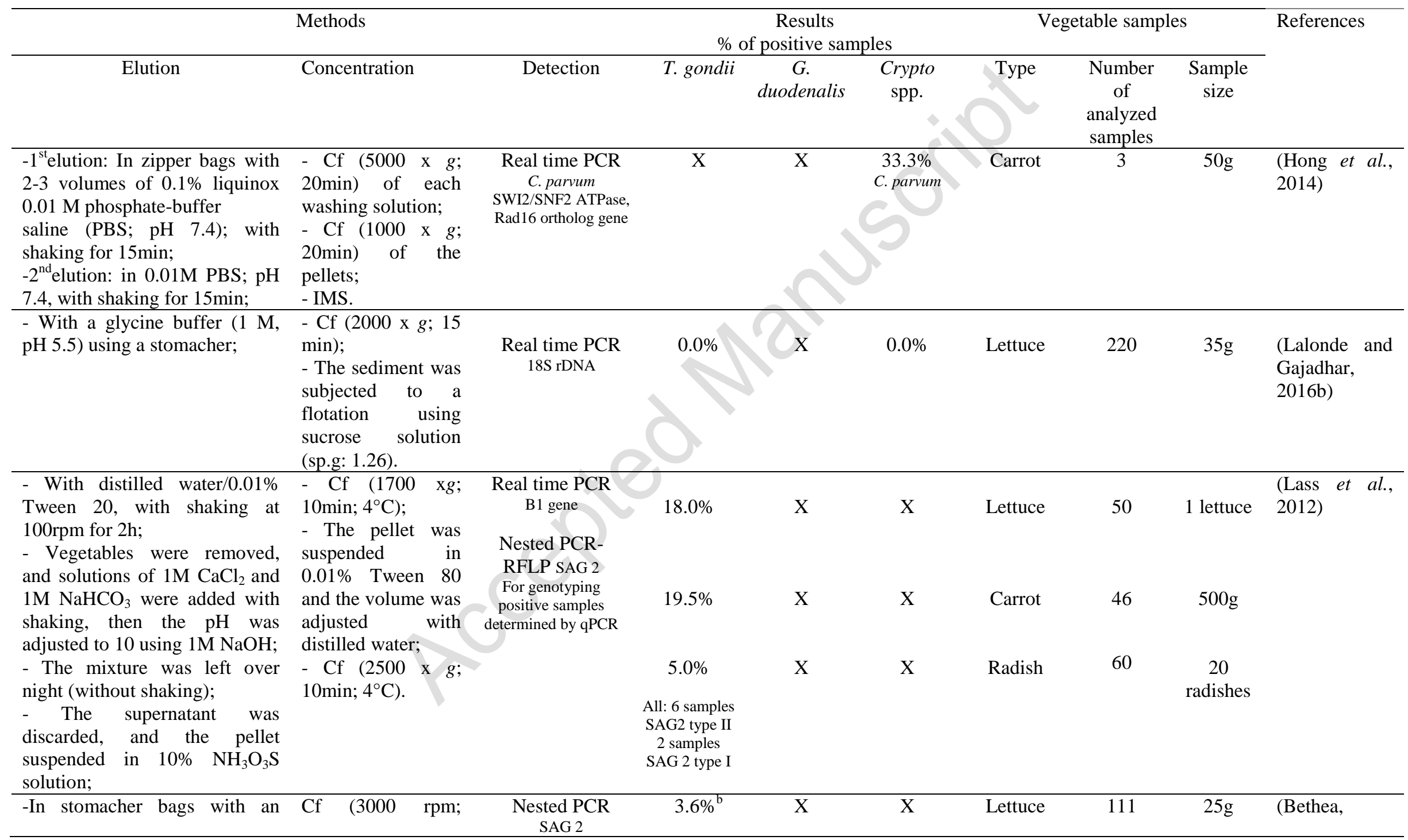




\begin{tabular}{|c|c|c|c|c|c|c|c|c|c|}
\hline $\begin{array}{l}\text { elution buffer (Laureth } 12,1 \mathrm{M} \\
\text { Tris buffer, pH } 7.4 \text {; EDTA; } \\
\text { Antifoam A), by rocking for } \\
15 \text { min on each side. }\end{array}$ & $20 \mathrm{~min})$ & & $\begin{array}{l}2.0 \%^{\mathrm{a}} \\
4.3 \%^{\mathrm{b}} \\
0.0 \%^{\mathrm{a}}\end{array}$ & $\begin{array}{l}\mathrm{X} \\
\mathrm{X} \\
\mathrm{X}\end{array}$ & $\begin{array}{l}X \\
X \\
X\end{array}$ & Parsley & $\begin{array}{c}100 \\
47 \\
100\end{array}$ & $\begin{array}{l}25 \mathrm{~g} \\
25 \mathrm{~g} \\
25 \mathrm{~g}\end{array}$ & 2014) \\
\hline $\begin{array}{l}\text {-In plastic bags with } 1 \% \text { Tween } \\
80 \text { by hand shaking for } 1 \mathrm{~min} \text {; } \\
\text {-Filtration using cellulose ester } \\
\text { membrane }(0.3 \mu \mathrm{m} \text { pore size }) \\
\text { under pressure. }\end{array}$ & $\begin{array}{l}\mathrm{Cf}(600 \text { x } g ; \\
15 \mathrm{~min}) .\end{array}$ & $\begin{array}{c}\text { PCR } \\
\text { B1 gene, } \\
\text { a } 529 \text { bp repeat } \\
\text { fragment }\end{array}$ & $\begin{array}{c}1.6 \% \\
20.0 \%\end{array}$ & $\begin{array}{l}X \\
X\end{array}$ & $\begin{array}{l}\mathrm{X} \\
\mathrm{X}\end{array}$ & $\begin{array}{l}\text { Lettuce } \\
\text { Parsley }\end{array}$ & $\begin{array}{c}62 \\
5\end{array}$ & $\begin{array}{l}50 \mathrm{~g} \\
50 \mathrm{~g}\end{array}$ & $\begin{array}{l}\text { (Marchioro et } \\
\text { al., 2016) }\end{array}$ \\
\hline $\begin{array}{l}\text { - With } 1 \mathrm{M} \text { Glycine, } \mathrm{pH} 5.5 \text {, in a } \\
\text { filtered stomacher bag for } 30 \mathrm{sec}\end{array}$ & $\begin{array}{l}-\mathrm{Cf}(2500 \text { x } g ; \\
\text { 10min); } \\
\text { - IMS. }\end{array}$ & IFA & $\mathrm{X}$ & $61.5 \%$ & & Lettuce & 19 & $50 \mathrm{~g}$ & $\begin{array}{l}\text { (Amoros et } \\
\text { al., 2010) }\end{array}$ \\
\hline $\begin{array}{l}\text { - In an elution buffer containing } \\
\text { salts, detergent and antifoam A; } \\
\text { - Washing, twice, in a rotating } \\
\text { drum, for } 1-5 \mathrm{~min}\end{array}$ & $\begin{array}{l}-\mathrm{Cf}(1000 \text { x } g ; \\
\text { 10min); } \\
\text { - IMS. }\end{array}$ & IFA & $\begin{array}{l}X \\
X \\
X\end{array}$ & $\begin{array}{l}2.0 \% \\
0.0 \% \\
17.0 \%\end{array}$ & $\begin{array}{l}4.0 \% \\
0.0 \% \\
0.0 \%\end{array}$ & $\begin{array}{l}\text { Lettuce } \\
\text { Parsley } \\
\text { Radish }\end{array}$ & $\begin{array}{c}125 \\
7 \\
6\end{array}$ & $\begin{array}{l}100 \mathrm{~g} \\
10-80 \mathrm{~g} \\
50 \mathrm{~g}\end{array}$ & $\begin{array}{l}\text { (Robertson } \\
\text { and Gjerde, } \\
\text { 2001a) }\end{array}$ \\
\hline $\begin{array}{l}\text {-Stomaching in stomacher bags } \\
\text { with } 1 \mathrm{M} \text { Glycine for } 1 \mathrm{~min} \text {. }\end{array}$ & $\begin{array}{l}-\mathrm{Cf}(2500 \text { x } g \\
\left.10 \mathrm{~min} ; 15^{\circ} \mathrm{C}\right) ; \\
\text { - IMS }\end{array}$ & $\begin{array}{c}\text { IFA } \\
\text { Nested PCR-RFLP } \\
\text { (for positive samples } \\
\text { determined by IFA) } \\
\text { (18S rRNA, COWP, } \\
\text { Lib13) } \\
\end{array}$ & X & $X$ & $0.0 \%$ & Lettuce & 24 & $30 \mathrm{~g}$ & $\begin{array}{l}\text { (Rzezutka et } \\
\text { al., 2010) }\end{array}$ \\
\hline $\begin{array}{l}\text { In stomacher bags, with } \\
\text { Glycine buffer for } 4 \mathrm{~min} \text {, by } \\
\text { hand manipulation; }\end{array}$ & $\begin{array}{l}-\mathrm{Cf}(15500 \mathrm{rcf} ; \\
\text { 10min); } \\
\text { - IMS. }\end{array}$ & $\begin{array}{c}\text { IFA } \\
\text { PCR (for positive } \\
\text { samples determined by } \\
\text { IFA) } \\
\text { (Giardia } 18 \text { SrRNA) } \\
\text { (Crypto 18SrRNA, } \\
\text { COWP) }\end{array}$ & $\begin{array}{l}X \\
X \\
X \\
X\end{array}$ & $\begin{array}{c}0.0 \% \\
14.3 \% \\
4.0 \% \\
0.0 \%\end{array}$ & $\begin{array}{l}0.0 \% \\
7.1 \% \\
0.0 \% \\
1.1 \%\end{array}$ & $\begin{array}{l}\text { Lettuce } \\
\text { Coriander } \\
\text { Carrot } \\
\text { Radish }\end{array}$ & 284 & $30 \mathrm{~g}$ & $\begin{array}{l}\text { (Utaaker et } \\
\text { al., 2017) }\end{array}$ \\
\hline $\begin{array}{l}\text { - With physiological saline } \\
\text { solution }(0.85 \% \mathrm{NaCl}) ; \\
\text { - The washing solution was left } \\
10 \mathrm{~h} \text { to sediment, the } \\
\text { supernatant was discarded }\end{array}$ & $\begin{array}{l}\mathrm{Cf} \quad(2164 \quad \mathrm{x} \quad g ; \\
15 \mathrm{~min}) .\end{array}$ & $\begin{array}{c}\text { ME: Lugol's } \\
\text { iodine staining }\end{array}$ & $\mathrm{X}$ & $4.0 \%$ & $X$ & Lettuce & 27 & $100 \mathrm{~g}$ & $\begin{array}{l}\text { (Abougrain et } \\
\text { al., 2010) }\end{array}$ \\
\hline $\begin{array}{l}\text { - With a solution of (TBS: } \\
\text { 20mM Tris base, 0.5mM } \\
\text { Sodium chloride, } 0.2 \% \text { Tween } \\
\text { 20), using a mechanical shaker } \\
\text { at } 150 \text { rpm for } 30 \text { min; } \\
\text { - The washing solution was left }\end{array}$ & $\begin{array}{l}\text { Cf }(1500 \quad \text { rpm; } \\
5 \mathrm{~min}) .\end{array}$ & $\begin{array}{l}\text { ME: Lugol's } \\
\text { iodine and ZN } \\
\text { staining }\end{array}$ & $\begin{array}{c}41.0 \% \\
5.7 \% \\
12.2 \%\end{array}$ & $\begin{array}{l}2.7 \% \\
0.0 \% \\
7.3 \%\end{array}$ & $\begin{array}{l}0.0 \% \\
3.4 \% \\
2.4 \%\end{array}$ & $\begin{array}{c}\text { Lettuce } \\
\text { Parsley } \\
\text { Carrot }\end{array}$ & $\begin{array}{l}73 \\
88 \\
41\end{array}$ & $\begin{array}{l}100 \mathrm{~g} \\
100 \mathrm{~g} \\
100 \mathrm{~g}\end{array}$ & $\begin{array}{l}\text { (Ahmad et al., } \\
\text { 2016) }\end{array}$ \\
\hline
\end{tabular}




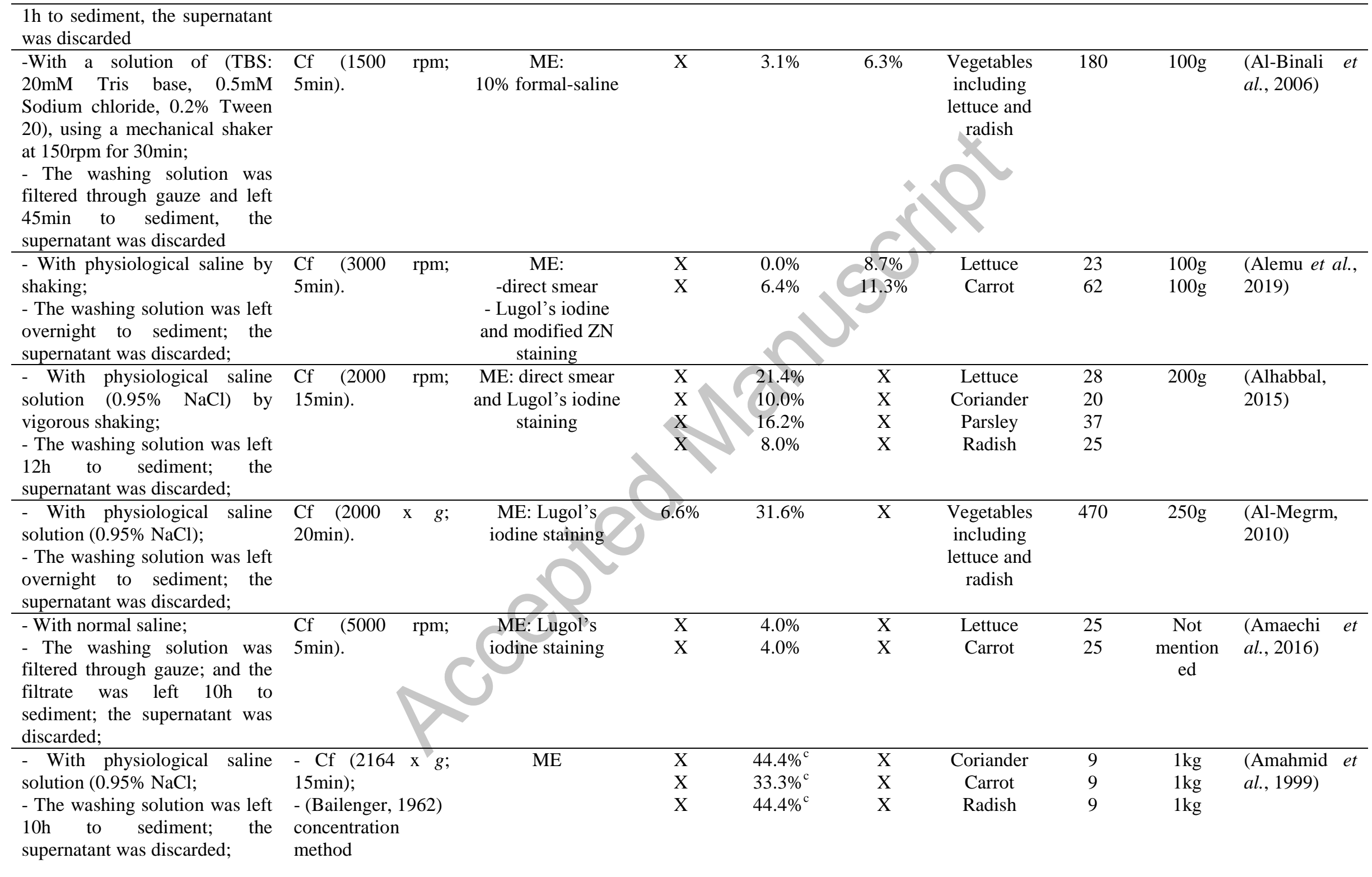




\begin{tabular}{|c|c|c|c|c|c|c|c|c|c|c|}
\hline $\begin{array}{l}\text { - Samples were put in } \\
\text { containers with water/ } 0.2 \% \\
\text { dish washing liquid for } 6 \mathrm{~h} \text {, and } \\
\text { were stirred regularly every half } \\
\text { hour; } \\
\text { - The solution was left } 16 \mathrm{~h} \text { to } \\
\text { sediment, the supernatant was } \\
\text { discarded; } \\
\text { - The residue was filtered } \\
\text { through a sieve }(150 \mu \mathrm{m} \text { pore } \\
\text { size); }\end{array}$ & $\begin{array}{l}\mathrm{Cf} \quad(1000 \\
5 \mathrm{~min}) \text { twice. }\end{array}$ & rpm; & $\begin{array}{l}\text { ME: Lugol's } \\
\text { iodine and } \mathrm{ZN} \\
\text { staining }\end{array}$ & $\mathrm{X}$ & $7.5 \%$ & $40.0 \%$ & Lettuce & 80 & $500 \mathrm{~g}$ & $\begin{array}{l}\text { (Avazpoor et } \\
\text { al., 2015) }\end{array}$ \\
\hline $\begin{array}{l}\text { - With physiological saline } \\
\text { solution }(0.85 \% \mathrm{NaCl}) ; \\
\text { - The washing solution was left } \\
24 \mathrm{~h} \text { to sediment; the } \\
\text { supernatant was discarded; }\end{array}$ & $\begin{array}{l}\mathrm{Cf} \quad(2000 \\
5 \mathrm{~min}) .\end{array}$ & $\mathrm{rpm}$ & $\begin{array}{l}\text { ME: Lugol's } \\
\text { iodine staining }\end{array}$ & $\mathrm{X}$ & $19.4 \%$ & & Lettuce & 72 & $100 \mathrm{~g}$ & $\begin{array}{l}\text { (Benti and } \\
\text { Gemechu, } \\
\text { 2014) }\end{array}$ \\
\hline $\begin{array}{l}\text {-Using sterile peptonated water } \\
0.1 \%\end{array}$ & $\begin{array}{l}\text { Cf }(900 x \\
\min )\end{array}$ & $g ; 15$ & $\begin{array}{l}\text { ME: } \\
\text { ZN and Weber } \\
\text { staining }\end{array}$ & $\mathrm{X}$ & & $2.0 \%$ & $\begin{array}{l}\text { Vegetables } \\
\text { including } \\
\text { lettuce and } \\
\text { parsley }\end{array}$ & 250 & $\begin{array}{l}\text { Not } \\
\text { mention } \\
\text { ed }\end{array}$ & $\begin{array}{l}\text { (Calvo et al., } \\
\text { 2004) }\end{array}$ \\
\hline $\begin{array}{l}\text { - With physiological saline } \\
\text { solution }(0.95 \% \mathrm{NaCl}) ; \\
\text { - The washing solution was left } \\
24 \mathrm{~h} \text { to sediment, the } \\
\text { supernatant was discarded; }\end{array}$ & $\begin{array}{l}\text { Cf }(2000 \\
5 \min ) .\end{array}$ & $g$ & $\begin{array}{l}\text { ME: Lugol's } \\
\text { iodine staining }\end{array}$ & $\mathrm{X}$ & $\begin{array}{l}\text { Im.Veg } \\
7.0 \% \\
\text { N. Veg } \\
9.0 \%\end{array}$ & $\mathrm{X}$ & $\begin{array}{l}\text { Vegetables } \\
\text { including } \\
\text { (lettuce, } \\
\text { parsley, } \\
\text { coriander, } \\
\text { radish) } \\
\end{array}$ & $\begin{array}{l}\text { Im. Veg } \\
\quad 96 \\
\text { N.Veg } \\
\quad 45\end{array}$ & $\begin{array}{l}250 \mathrm{~g} \\
250 \mathrm{~g}\end{array}$ & $\begin{array}{l}\text { (Daryani et } \\
\text { al., 2008) }\end{array}$ \\
\hline $\begin{array}{l}\text {-Washing using three elution } \\
\text { buffers (tap water, saline } \\
0.85 \% \text {, PBS), with vigorous } \\
\text { shaking (manually) for } 3 \text { min; }\end{array}$ & $\begin{array}{l}\text { Cf }(3000 \\
15 \min ) .\end{array}$ & $g$ & $\begin{array}{c}\text { ME: } \\
\text { - direct smear } \\
\text { - Lugol's iodine } \\
\text { and modified ZN } \\
\text { staining }\end{array}$ & $\mathrm{X}$ & $6.0 \%$ & $17.0 \%$ & $\begin{array}{l}\text { Vegetables } \\
\text { including } \\
\text { carrot and } \\
\text { lettuce }\end{array}$ & 168 & $\begin{array}{l}100- \\
150 \mathrm{~g}\end{array}$ & $\begin{array}{l}\text { (Duedu et al., } \\
\text { 2014) }\end{array}$ \\
\hline $\begin{array}{l}\text { - Pre- washing with tap water, } \\
\text { for 6-7 min; } \\
\text { - Washing with a solution of } \\
\text { (PBS; pH 7.4, 0.01\% Tween } \\
80 \text { ); } \\
\text { - The washing solution was } \\
\text { filtered through gauze; }\end{array}$ & $\begin{array}{l}\text { Cf }(2000 \\
\text { 30min }) .\end{array}$ & $\mathrm{x} \quad g$ & $\begin{array}{c}\text { ME: } \\
\text {-direct smear } \\
\text { - Lugol's iodine } \\
\text { and modified ZN } \\
\text { staining }\end{array}$ & $\mathrm{X}$ & $\begin{array}{l}15.0 \% \\
5.0 \%\end{array}$ & $\begin{array}{l}43.3 \% \\
33.3 \%\end{array}$ & $\begin{array}{l}\text { Lettuce } \\
\text { Parsley }\end{array}$ & $\begin{array}{l}60 \\
60\end{array}$ & $\begin{array}{l}200 \mathrm{~g} \\
200 \mathrm{~g}\end{array}$ & $\begin{array}{l}\text { (El Said Said, } \\
\text { 2012) }\end{array}$ \\
\hline - With three solutions & - Cf $(2000 x$ & $g ; 30$ & ME: modified ZN & $X$ & $\mathrm{X}$ & $26.3 \%$ & Lettuce & 80 & $150 \mathrm{~g}$ & (El Sherbini $e t$ \\
\hline
\end{tabular}




\begin{tabular}{|c|c|c|c|c|c|c|c|c|c|}
\hline $\begin{array}{l}\text { (separately), tap water, saline } \\
(0.85 \%) \text { and PBS, with manual } \\
\text { shaking for } 3 \mathrm{~min} \text {; } \\
\text { - The eluent was filtered } \\
\text { through gauze. }\end{array}$ & $\begin{array}{l}\text { min); } \\
\text {-The residue was } \\
\text { concentrated by } \\
\text { sucrose flotation } \\
\text { (specific gravity } \\
(\text { sp.g):1.18). }\end{array}$ & staining & $\begin{array}{l}\mathrm{X} \\
\mathrm{X}\end{array}$ & $\begin{array}{l}\mathrm{X} \\
\mathrm{X}\end{array}$ & $\begin{array}{l}20.5 \% \\
20.0 \%\end{array}$ & $\begin{array}{r}\text { Parsley } \\
\text { Carrot }\end{array}$ & $\begin{array}{l}88 \\
20\end{array}$ & $\begin{array}{l}150 \mathrm{~g} \\
150 \mathrm{~g}\end{array}$ & al., 2016) \\
\hline $\begin{array}{l}\text { - Soaking for } 15 \mathrm{mn} \text { in } \\
\text { physiological saline; } \\
\text { - Washing with normal saline } \\
\text { by vigorous shaking for } 15 \mathrm{~min} \text {; } \\
\text { - The washing solution was left } \\
\text { 10h to sediment; } \\
\text { - washing solution was filtered } \\
\text { through a sieve }(452 \mu \mathrm{m}) \text { to } \\
\text { remove debris; }\end{array}$ & $\begin{array}{l}\text { - Cf (2000 rpm; } \\
15 \mathrm{~min}) ; \\
\text { - The supernatant } \\
\text { was concentrated } \\
\text { by zinc sulfate } \\
\text { flotation. }\end{array}$ & $\begin{array}{c}\text { ME: } \\
\text { - direct smear; } \\
\text { - Lugol's iodine } \\
\text { and modified ZN } \\
\text { staining }\end{array}$ & $X$ & $\begin{array}{l}34.0 \% \\
25.5 \%\end{array}$ & $X$ & Parsley & $\begin{array}{l}101 \\
102\end{array}$ & $\begin{array}{l}200 \mathrm{~g} \\
200 \mathrm{~g}\end{array}$ & $\begin{array}{l}\text { (Eraky et al., } \\
\text { 2014) }\end{array}$ \\
\hline $\begin{array}{l}\text { - With physiological saline } \\
\text { solution }(0.95 \% \mathrm{NaCl} \text {; } \\
\text { - The washing solution was left } \\
10 \mathrm{~h} \text { to sediment; the } \\
\text { supernatant was discarded; }\end{array}$ & $\begin{array}{l}-\mathrm{Cf}(2164 \quad \mathrm{x} \quad g \\
; 15 \mathrm{~min}) ; \\
-\quad \text { Concentration } \\
\text { following } \\
\text { (Bailenger, 1962) }\end{array}$ & $\mathrm{ME}$ & $\begin{array}{l}X \\
X\end{array}$ & $\begin{array}{l}20.0 \% \\
0.0 \%\end{array}$ & $\begin{array}{l}X \\
X\end{array}$ & $\begin{array}{l}\text { Lettuce } \\
\text { Parsley }\end{array}$ & $\begin{array}{l}15 \\
20\end{array}$ & $\begin{array}{l}100 \mathrm{~g} \\
100 \mathrm{~g}\end{array}$ & $\begin{array}{l}\text { (Erdoğ rul } \\
\text { and Şener, } \\
2005)\end{array}$ \\
\hline $\begin{array}{l}\text { - With physiological saline } \\
\text { solution }(0.95 \% \mathrm{NaCl}) \text {, by } \\
\text { vigorous shaking; } \\
\text { - The washing solution was left } \\
12 \mathrm{~h} \text { to sediment, the } \\
\text { supernatant was discarded; }\end{array}$ & $\begin{array}{l}\text { Cf (2000 rpm; } \\
15 \mathrm{~min}) .\end{array}$ & $\begin{array}{c}\text { ME: } \\
\text { direct smear and } \\
\text { Lugol's iodine } \\
\text { staining }\end{array}$ & $X$ & $0.0 \%$ & $X$ & Radish & 55 & $250 \mathrm{~g}$ & $\begin{array}{l}\text { (Ezatpour et } \\
\text { al., 2013) }\end{array}$ \\
\hline $\begin{array}{l}\text { With physiological saline } \\
\text { solution }(0.95 \% \mathrm{NaCl}) \text {; } \\
\text { - The washing solution was left } \\
\text { overnight to sediment, the } \\
\text { supernatant was discarded; }\end{array}$ & $\begin{array}{l}\text { Cf }(2000 \quad \text { x } \quad g ; \\
15 \text { min }) .\end{array}$ & $\begin{array}{c}\text { ME: } \\
\text { direct smear and } \\
\text { Lugol's iodine } \\
\text { staining }\end{array}$ & $\mathrm{X}$ & $8.2 \%$ & $\mathrm{X}$ & $\begin{array}{l}\text { Vegetables } \\
\text { including } \\
\text { coriander, } \\
\text { parsley and } \\
\text { radish } \\
\end{array}$ & 304 & $250 \mathrm{~g}$ & $\begin{array}{l}\text { (Fallah et al., } \\
\text { 2012) }\end{array}$ \\
\hline $\begin{array}{l}\text { - With physiological saline } \\
\text { solution }(0.9 \% \mathrm{NaCl}), \text { by } \\
\text { vigorous shaking; } \\
\text { - The washing solution was left } \\
\text { overnight to sediment; the } \\
\text { supernatant was discarded; }\end{array}$ & $\begin{array}{l}\text { - Cf }(2000 \text { rpm; } \\
15 \mathrm{~min}) ; \\
\text { - Sucrose flotation } \\
\text { (sp.g: } 1.21) \text { at } 1500 \\
\text { x } g \text { for } 5 \mathrm{~min} ;\end{array}$ & $\mathrm{ME}$ & $\mathrm{X}$ & $\begin{array}{l}X \\
X\end{array}$ & $\begin{array}{c}\text { Un. Veg } \\
2.9 \% \\
\text { Pre. Veg } \\
1.8 \%\end{array}$ & $\begin{array}{l}\text { Vegetables } \\
\text { including } \\
\text { lettuce and } \\
\text { carrot }\end{array}$ & $\begin{array}{c}\text { Un. Veg } \\
453 \\
\text { Pre. Veg } \\
448\end{array}$ & $\begin{array}{l}250 \mathrm{~g} \\
250 \mathrm{~g}\end{array}$ & $\begin{array}{l}\text { (Fallah et al., } \\
\text { 2016) }\end{array}$ \\
\hline $\begin{array}{l}\text { With physiological saline } \\
\text { solution }(0.85 \% \mathrm{NaCl}) ;\end{array}$ & $\begin{array}{l}\text { Cf }(2164 \quad \text { x } g \\
15 \min ) .\end{array}$ & $\begin{array}{l}\text { ME: Lugol's } \\
\text { iodine staining }\end{array}$ & $\mathrm{X}$ & $0.0 \%$ & $\mathrm{X}$ & Lettuce & 50 & $100 \mathrm{~g}$ & $\begin{array}{l}\text { (Gabre and } \\
\text { Shakir, 2016) }\end{array}$ \\
\hline
\end{tabular}




\begin{tabular}{|c|c|c|c|c|c|c|c|c|c|}
\hline $\begin{array}{l}\text { - The washing solution was left } \\
10 \mathrm{~h} \text { to sediment, the } \\
\text { supernatant was discarded; }\end{array}$ & & & $\mathrm{X}$ & $8.0 \%$ & $\mathrm{X}$ & Carrot & 50 & $100 \mathrm{~g}$ & \\
\hline $\begin{array}{l}\text { - With normal saline, by } \\
\text { vigorous shaking; }\end{array}$ & $\begin{array}{l}\text { Cf }(2000 \quad \mathrm{rpm} \\
15 \mathrm{~min})\end{array}$ & $\begin{array}{l}\text { ME: direct smear } \\
\text { and Lugol's iodine } \\
\text { staining }\end{array}$ & $\begin{array}{l}X \\
X \\
X \\
X \\
X\end{array}$ & $\begin{array}{c}0.0 \% \\
10.0 \% \\
8.3 \% \\
20.0 \% \\
25.0 \%\end{array}$ & $\begin{array}{l}X \\
X \\
X \\
X \\
X\end{array}$ & $\begin{array}{l}\text { Lettuce } \\
\text { Parsley } \\
\text { Coriander } \\
\text { Carrot } \\
\text { Radish }\end{array}$ & $\begin{array}{c}5 \\
10 \\
12 \\
10 \\
4\end{array}$ & $\begin{array}{l}\text { Not } \\
\text { mention } \\
\text { ed }\end{array}$ & $\begin{array}{l}\text { (Hassan et al., } \\
\text { 2012) }\end{array}$ \\
\hline $\begin{array}{l}\text { - With physiological saline } \\
\text { solution }(0.85 \% \mathrm{NaCl}), \text { by } \\
\text { shaking for } 20 \mathrm{~min} \\
\text {-The washing solution was left } \\
\text { overnight to sediment; the } \\
\text { supernatant was discarded; }\end{array}$ & $\begin{array}{l}\mathrm{Cf} \quad(2000 \quad \mathrm{rcf} ; \\
15 \mathrm{~min})\end{array}$ & $\begin{array}{l}\text { ME: Lugol's } \\
\text { iodine staining }\end{array}$ & $\mathrm{X}$ & $\begin{array}{l}23.3 \% \\
0.0 \%\end{array}$ & $\mathrm{X}$ & $\begin{array}{l}\text { Lettuce } \\
\text { Parsley }\end{array}$ & $\begin{array}{l}30 \\
42\end{array}$ & $\begin{array}{l}250 \mathrm{~g} \\
250 \mathrm{~g}\end{array}$ & (Ismail, 2016) \\
\hline - With distilled water. & $\begin{array}{l}\text { Flotation and } \\
\text { formol-ether } \\
\text { concentration }\end{array}$ & ME & $\mathrm{X}$ & $\begin{array}{l}0.0 \% \\
0.0 \%\end{array}$ & $\mathrm{X}$ & $\begin{array}{c}\text { Lettuce } \\
\text { Carrot }\end{array}$ & $\begin{array}{c}82 \\
187\end{array}$ & $\begin{array}{c}\text { Not } \\
\text { mention } \\
\text { ed }\end{array}$ & $\begin{array}{l}\text { (Istifanus and } \\
\text { Panda, 2018) }\end{array}$ \\
\hline $\begin{array}{l}\text {-With distilled water, in } \\
\text { stomacher bags, using } \\
\text { stomacher for } 2 \mathrm{~min} \text { at } 260 \mathrm{rpm} \text {. }\end{array}$ & $\begin{array}{l}-\mathrm{Cf}(1200 \text { x } g ; \\
10 \mathrm{~min}) . \\
\text {-Concentration } \\
\text { following } \\
\text { (Bailenger, 1962) } \\
\end{array}$ & $\begin{array}{l}\text { ME: modified ZN } \\
\text { staining }\end{array}$ & $X$ & $X$ & $\begin{array}{l}33.3 \% \\
55.5 \%\end{array}$ & $\begin{array}{l}\text { Coriander } \\
\text { Lettuce }\end{array}$ & 9 & $\begin{array}{l}10 \mathrm{~g} \\
10 \mathrm{~g}\end{array}$ & $\begin{array}{ll}\text { (Le Quynh } \\
\text { Chau et al., } \\
\text { 2014) }\end{array}$ \\
\hline $\begin{array}{l}\text {-With physiological saline } \\
\text { solution }(0.95 \% \mathrm{NaCl}) \text {; } \\
\text { - The wash was left for } 10 \mathrm{~h} \text { to } \\
\text { sediment; the supernatant was } \\
\text { discarded; }\end{array}$ & $\begin{array}{l}-\quad \mathrm{Cf}(1500 \text { rpm; } \\
5 \mathrm{~min}) ; \\
-\quad \text { Flotation using } \\
\text { sucrose solution } \\
\text { (sp.g 1.21). }\end{array}$ & $\begin{array}{l}\text { ME: modified ZN } \\
\text { staining }\end{array}$ & $\mathrm{X}$ & $\begin{array}{l}\mathrm{X} \\
\mathrm{X}\end{array}$ & $\begin{array}{l}48.0 \% \\
24.0 \%\end{array}$ & $\begin{array}{l}\text { Lettuce } \\
\text { Carrot }\end{array}$ & $\begin{array}{l}25 \\
25\end{array}$ & $\begin{array}{l}250 \mathrm{~g} \\
250 \mathrm{~g}\end{array}$ & $\begin{array}{l}\text { (Maikai et al., } \\
\text { 2013) }\end{array}$ \\
\hline - With $10 \%$ formal saline; & $\begin{array}{l}-\mathrm{Cf}(3000 \mathrm{rpm} \\
5 \mathrm{~min})\end{array}$ & $\begin{array}{l}\text { ME: direct smear } \\
\text { and Lugol's iodine } \\
\text { staining }\end{array}$ & $\begin{array}{l}X \\
X \\
X\end{array}$ & $\begin{array}{l}9.1 \% \\
2.0 \% \\
4.2 \%\end{array}$ & $\begin{array}{l}X \\
X \\
X\end{array}$ & $\begin{array}{l}\text { Lettuce } \\
\text { Carrot } \\
\text { Radish }\end{array}$ & $\begin{array}{l}11 \\
50 \\
24\end{array}$ & $\begin{array}{l}\text { Not } \\
\text { mention } \\
\text { ed }\end{array}$ & $\begin{array}{l}\text { (Mohamed et } \\
\text { al., 2016) }\end{array}$ \\
\hline $\begin{array}{l}\text { - With a solution of } 1 \% \text { sodium } \\
\text { dodecyl sulfate (SDS) / } 0.1 \% \\
\text { Tween } 80 \text {, for } 10 \mathrm{~min} \text {; }\end{array}$ & $\begin{array}{l}\text { Cf }(3000 \quad \mathrm{rpm} ; \\
\text { 10min })\end{array}$ & $\begin{array}{l}\text { ME: fixation with } \\
\text { formaldehyde } 4 \% \\
\text { for } 10 \mathrm{~min} ; \\
\text { Lugol's iodine } \\
\text { staining }\end{array}$ & $\begin{array}{l}X \\
X \\
X\end{array}$ & $\begin{array}{c}8.3 \% \\
6.25 \% \\
0.0 \%\end{array}$ & $\begin{array}{l}X \\
X \\
X\end{array}$ & $\begin{array}{l}\text { Parsley } \\
\text { Coriander } \\
\text { Radish }\end{array}$ & $\begin{array}{c}12 \\
16 \\
9\end{array}$ & $\begin{array}{l}200 g \\
200 g \\
200 g\end{array}$ & $\begin{array}{lr}\text { (Nazemi et } \\
\text { al., 2012) } \\
\text { Using the } \\
\text { standard } \\
\text { method } \\
\text { proposed by } \\
\text { FDA }\end{array}$ \\
\hline Method 1: - Washing with & Method 1: Cf (2000 & ME: Lugol's & & & & Vegetables & & & \\
\hline
\end{tabular}




\begin{tabular}{|c|c|c|c|c|c|c|c|c|c|}
\hline $\begin{array}{l}\text { physiological saline solution } \\
(0.95 \% \mathrm{NaCl}) \text {; } \\
\text { - The washing solution was left } \\
\text { overnight to sediment; the } \\
\text { supernatant was discarded; } \\
\text { Method 2: - Washing with } \\
\text { sterilized water; } \\
\text { - The washing water was left } 8 \mathrm{~h} \\
\text { to sediment at room } \\
\text { temperature, the supernatant } \\
\text { was discarded; }\end{array}$ & $\begin{array}{l}\text { x } g ; 20 \min ) . \\
\text { Method 2: Cf ( } 3000 \\
\text { rpm; 5min). }\end{array}$ & iodine staining & $\mathrm{X}$ & $11.0 \%$ & $\mathrm{X}$ & $\begin{array}{l}\text { including } \\
\text { (lettuce, } \\
\text { parsley, } \\
\text { coriander, } \\
\text { radish) }\end{array}$ & 270 & $250 \mathrm{~g}$ & $\begin{array}{l}\text { (Olyaei and } \\
\text { Hajivandi, } \\
\text { 2013) }\end{array}$ \\
\hline $\begin{array}{l}\text { - With distilled water; } \\
\text { - The washing solution was } \\
\text { filtered through a double } \\
\text { layered sieve; }\end{array}$ & $\begin{array}{ll}\text { - Cf (2500 } & \text { rpm;1 } \\
\text { min); } & \\
\text { - Cysts } & \text { were } \\
\text { concentrated } & \text { using } \\
\text { (Umeche, } & 1991) \\
\text { technique. } & \\
\end{array}$ & ME & $X$ & $2.6 \%$ & & $\begin{array}{l}\text { Vegetables } \\
\text { including } \\
\text { lettuce }\end{array}$ & 761 & $100 \mathrm{~g}$ & $\begin{array}{l}\text { (Omowaye } \\
\text { and Audu, } \\
\text { 2012) }\end{array}$ \\
\hline $\begin{array}{l}\text { - With physiological saline } \\
\text { solution }(0.98 \% \mathrm{NaCl}) \text { by } \\
\text { shaking at } 150 \mathrm{rpm} \text { for } 30 \mathrm{~min} \text {; } \\
\text {-The washing solution was left } \\
\text { 45min to sediment, the } \\
\text { supernatant was discarded; }\end{array}$ & $\begin{array}{l}\text { - Cf (1500 rpm; } \\
5 \mathrm{~min}) ; \\
\text { - The pellet was } \\
\text { subjected to a } \\
\text { sucrose flotation } \\
\text { (sp.g 1.18). }\end{array}$ & $\begin{array}{l}\text { ME: modified ZN } \\
\text { staining }\end{array}$ & $\mathrm{X}$ & $\mathrm{X}$ & $\begin{array}{l}40.0 \% \\
31.4 \%\end{array}$ & $\begin{array}{l}\text { Lettuce } \\
\text { Carrot }\end{array}$ & 20 & $\begin{array}{l}250 \mathrm{~g} \\
250 \mathrm{~g}\end{array}$ & $\begin{array}{l}\text { (Rahman } \quad e t \\
\text { al., 2014) }\end{array}$ \\
\hline $\begin{array}{l}\text { - With a solution of } 1 \% \text { SDS, } \\
0.1 \% \text { Tween } 80 \text {, with stirring } \\
\text { for } 10 \text { min; } \\
\text { - The washing solution was left } \\
\text { 30min to sediment; the } \\
\text { supernatant was discarded; }\end{array}$ & $\begin{array}{l}\mathrm{Cf}(270 \quad \mathrm{x} \quad g ; \\
15 \min ) .\end{array}$ & $\begin{array}{c}\text { ME: } \text { modified } \mathrm{ZN} \\
\text { staining }\end{array}$ & $X$ & $X$ & $6.7 \%$ & Coriander & 90 & $200 \mathrm{~g}$ & $\begin{array}{l}\text { (Ranjbar- } \\
\text { Bahadori } \\
\text { al., 2013) }\end{array}$ \\
\hline $\begin{array}{l}\text { - With physiological saline } \\
\text { solution }(0.95 \% \mathrm{NaCl}) ; \\
\text { - The washing solution was left } \\
\text { overnight to sediment; the } \\
\text { supernatant was discarded; }\end{array}$ & $\begin{array}{l}\mathrm{Cf}(3000 \quad \mathrm{rpm} ; \\
5 \mathrm{~min}) .\end{array}$ & $\begin{array}{l}\text { ME: Lugol's } \\
\text { iodine staining }\end{array}$ & $\mathrm{X}$ & $13.3 \%$ & $\mathrm{X}$ & $\begin{array}{l}\text { Vegetables } \\
\text { including } \\
\text { lettuce, } \\
\text { parsley and } \\
\text { radish } \\
\end{array}$ & 135 & $500 \mathrm{~g}$ & $\begin{array}{l}\text { (Saki et al., } \\
2013)\end{array}$ \\
\hline $\begin{array}{l}\text { - With physiological saline } \\
\text { solution }(0.95 \% \mathrm{NaCl}) ; \\
\text { - The washing solution was left } \\
\text { overnight to sediment; the } \\
\text { supernatant was discarded; }\end{array}$ & $\begin{array}{l}\text { Cf }(2000 \quad \text { x } \quad g ; \\
20 \min ) .\end{array}$ & $\begin{array}{l}\text { ME: Lugol's } \\
\text { iodine staining }\end{array}$ & $\mathrm{X}$ & $16.3 \%$ & $X$ & $\begin{array}{l}\text { Vegetables } \\
\text { including } \\
\text { parsley }\end{array}$ & 72 & $\begin{array}{l}400- \\
500 \mathrm{~g}\end{array}$ & $\begin{array}{l}\text { (Saida and } \\
\text { Nooraldeen, } \\
\text { 2014) }\end{array}$ \\
\hline
\end{tabular}




\begin{tabular}{|c|c|c|c|c|c|c|c|c|c|}
\hline $\begin{array}{l}\text { - Pre-washing with tap water; } \\
\text { - Disinfection with calcium } \\
\text { hypochlorite solution 200ppm } \\
\text { for 30min; } \\
\text { - Rinsing in an automated } \\
\text { vegetable-fruit washer; } \\
\text { - Washing with a detergent } \\
\text { solution containing } 1 \%(\mathrm{w} / \mathrm{v}) \\
\text { SDS and } 0.1 \%(\mathrm{v} / \mathrm{v}) \text { Tween } 80 ; \\
\text { - Sonication for } 10 \mathrm{~min} \text {. }\end{array}$ & $\begin{array}{l}\text { Cf }(1500 \quad \text { x } \\
15 \text { min }) .\end{array}$ & ME & $\begin{array}{l}X \\
X \\
X \\
X\end{array}$ & $\begin{array}{l}0.0 \% \\
0.0 \% \\
0.0 \% \\
0.0 \%\end{array}$ & $\begin{array}{l}X \\
X \\
X \\
X\end{array}$ & $\begin{array}{l}\text { Lettuce } \\
\text { Parsley } \\
\text { Coriander } \\
\text { Radish }\end{array}$ & $\begin{array}{l}23 \\
21 \\
24 \\
29\end{array}$ & $\begin{array}{l}200 \mathrm{~g} \\
200 \mathrm{~g} \\
200 \mathrm{~g} \\
200 \mathrm{~g}\end{array}$ & $\begin{array}{l}\text { (Shahnazi and } \\
\text { Jafari-Sabet, } \\
\text { 2010) }\end{array}$ \\
\hline Washing with distilled water. & $\begin{array}{ll}\text {-Cf } \quad(250 & \text { rpm; } \\
\text { 1min }) . & \\
\text {-Zinc } & \text { sulfate } \\
\text { flotation. } & \end{array}$ & $\mathrm{ME}$ & $\mathrm{X}$ & $0 \%$ & $\mathrm{X}$ & Carrot & 10 & $\begin{array}{l}\text { Not } \\
\text { mention } \\
\text { ed }\end{array}$ & $\begin{array}{l}\text { (Simon-Oke } \\
\text { et al., 2014) }\end{array}$ \\
\hline $\begin{array}{l}\text {-Samples were kept eight hours } \\
\text { in water containing anionic } \\
\text { detergent (washing solution 1); } \\
\text {-Washing by high pressure } \\
\text { water for three times (washing } \\
\text { solution 2); } \\
\text {-The two washing solutions } \\
\text { were mixed and left 14h to } \\
\text { sediment; } \\
\text { - The supernatant was } \\
\text { discarded. }\end{array}$ & $\begin{array}{l}\text { Cf }(1500 \quad \mathrm{rpm} ; \\
5 \mathrm{~min}) .\end{array}$ & $\begin{array}{l}\text { ME: direct smear } \\
\text { and Lugol's iodine } \\
\text { staining }\end{array}$ & $\begin{array}{l}X \\
X \\
X \\
X\end{array}$ & $\begin{array}{l}25.0 \% \\
10.0 \% \\
5.0 \% \\
0.0 \%\end{array}$ & $\begin{array}{l}\mathrm{X} \\
\mathrm{X} \\
\mathrm{X} \\
\mathrm{X}\end{array}$ & $\begin{array}{l}\text { Lettuce } \\
\text { Coriander } \\
\text { Parsley } \\
\text { Radish }\end{array}$ & $\begin{array}{l}20 \\
20 \\
20 \\
20\end{array}$ & $\begin{array}{l}500 \mathrm{~g} \\
500 \mathrm{~g} \\
500 \mathrm{~g} \\
500 \mathrm{~g}\end{array}$ & $\begin{array}{l}\text { (Siyadatpanah } \\
\text { et al., 2013) }\end{array}$ \\
\hline $\begin{array}{l}\text { - With physiological normal } \\
\text { saline }(0.95 \% \text { NaCl }) \text { by } \\
\text { mechanical shaking; } \\
\text { - The top layer was discarded, } \\
\text { and the residue was filtered } \\
\text { through gauze. }\end{array}$ & $\begin{array}{l}\text { Cf }(2000 \quad \mathrm{rpm} ; \\
15 \mathrm{~min}) .\end{array}$ & ME: ZN staining & $\begin{array}{l}X \\
X\end{array}$ & $\begin{array}{l}X \\
X\end{array}$ & $\begin{array}{l}6.25 \% \\
6.25 \%\end{array}$ & $\begin{array}{l}\text { Parsley } \\
\text { Radish }\end{array}$ & $\begin{array}{l}80 \\
80\end{array}$ & $\begin{array}{l}400- \\
500 \mathrm{~g} \\
400- \\
500 \mathrm{~g}\end{array}$ & $\begin{array}{l}\text { (Sleman Ali et } \\
\text { al., 2018) }\end{array}$ \\
\hline $\begin{array}{l}\text { - With normal saline; } \\
\text { - The washing solution was left } \\
\text { overnight to sediment; the } \\
\text { supernatant was discarded; }\end{array}$ & $\begin{array}{l}\mathrm{Cf} \quad(3000 \\
5 \mathrm{~min}) .\end{array}$ & $\begin{array}{l}\text { ME: modified ZN } \\
\text { staining }\end{array}$ & $\mathrm{X}$ & $7.5 \%$ & $18,2 \%$ & $\begin{array}{l}\text { Vegetables } \\
\text { including } \\
\text { lettuce and } \\
\text { carrot }\end{array}$ & 360 & $200 \mathrm{~g}$ & $\begin{array}{l}\text { (Tefera et al., } \\
\text { 2014) }\end{array}$ \\
\hline
\end{tabular}




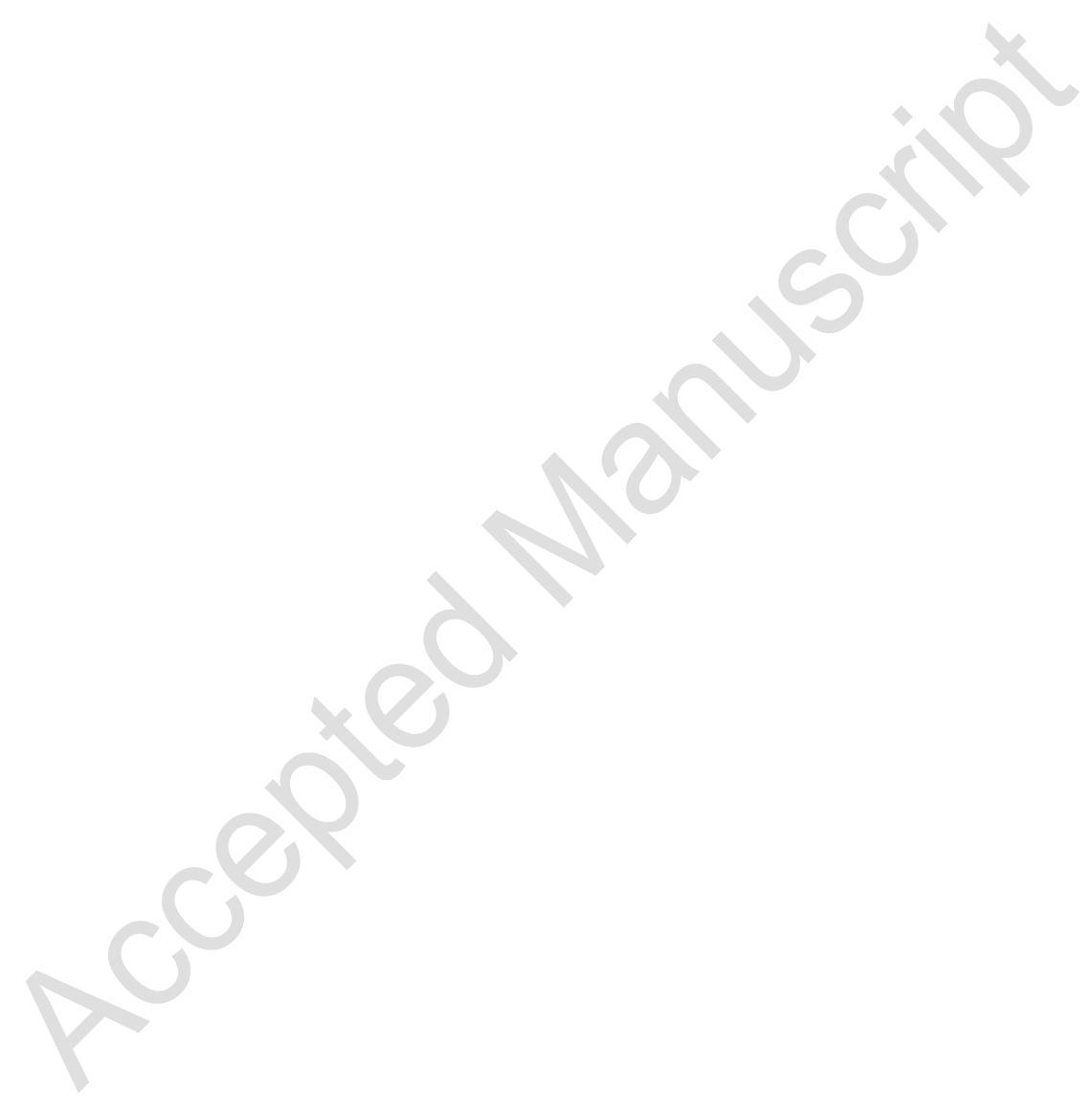


Table 2: Recovery efficiencies and detection limits of published methods for the detection of Cryptosporidium, G. duodenalis and T. gondii, in leafy greens and root vegetables

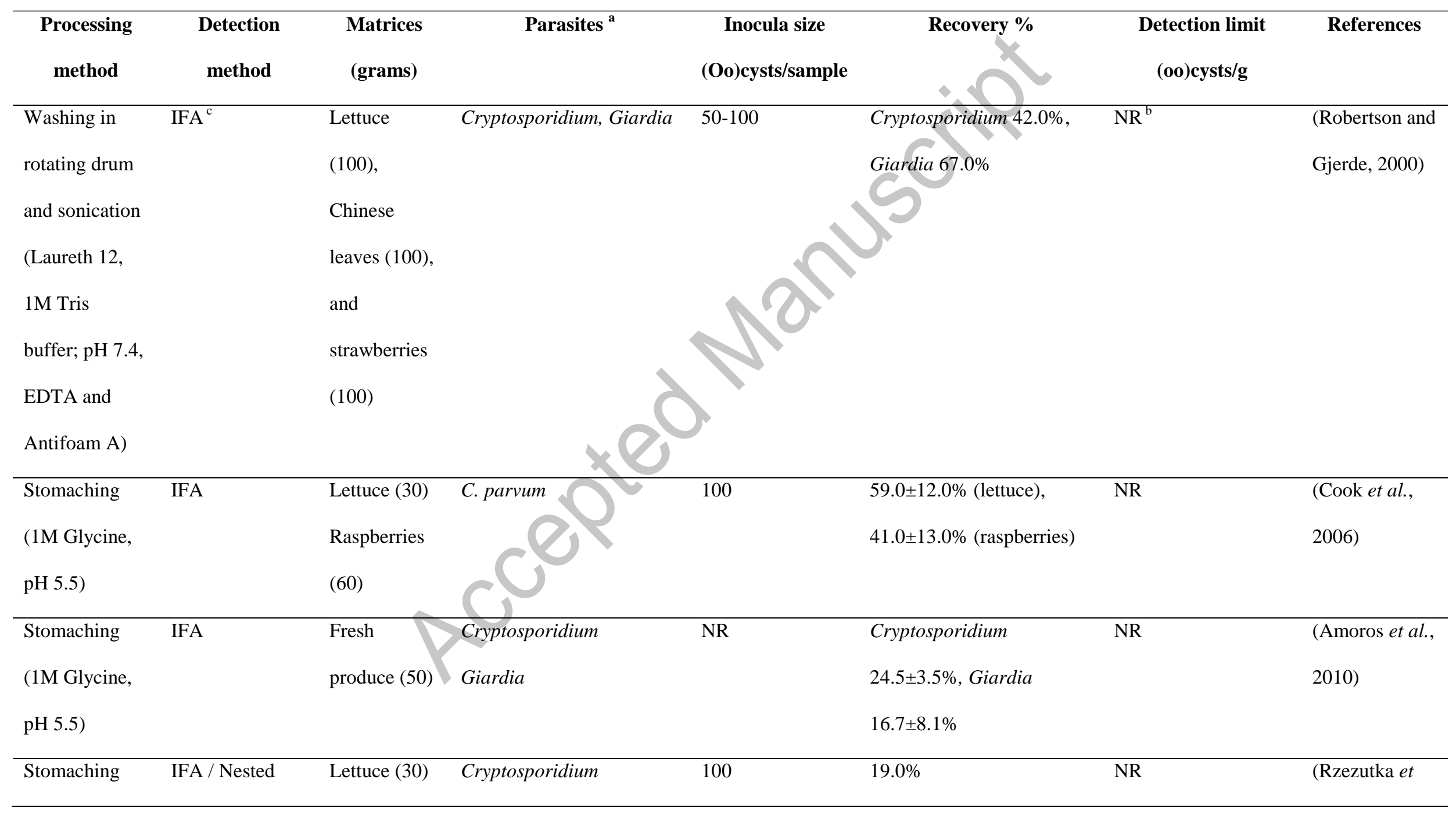




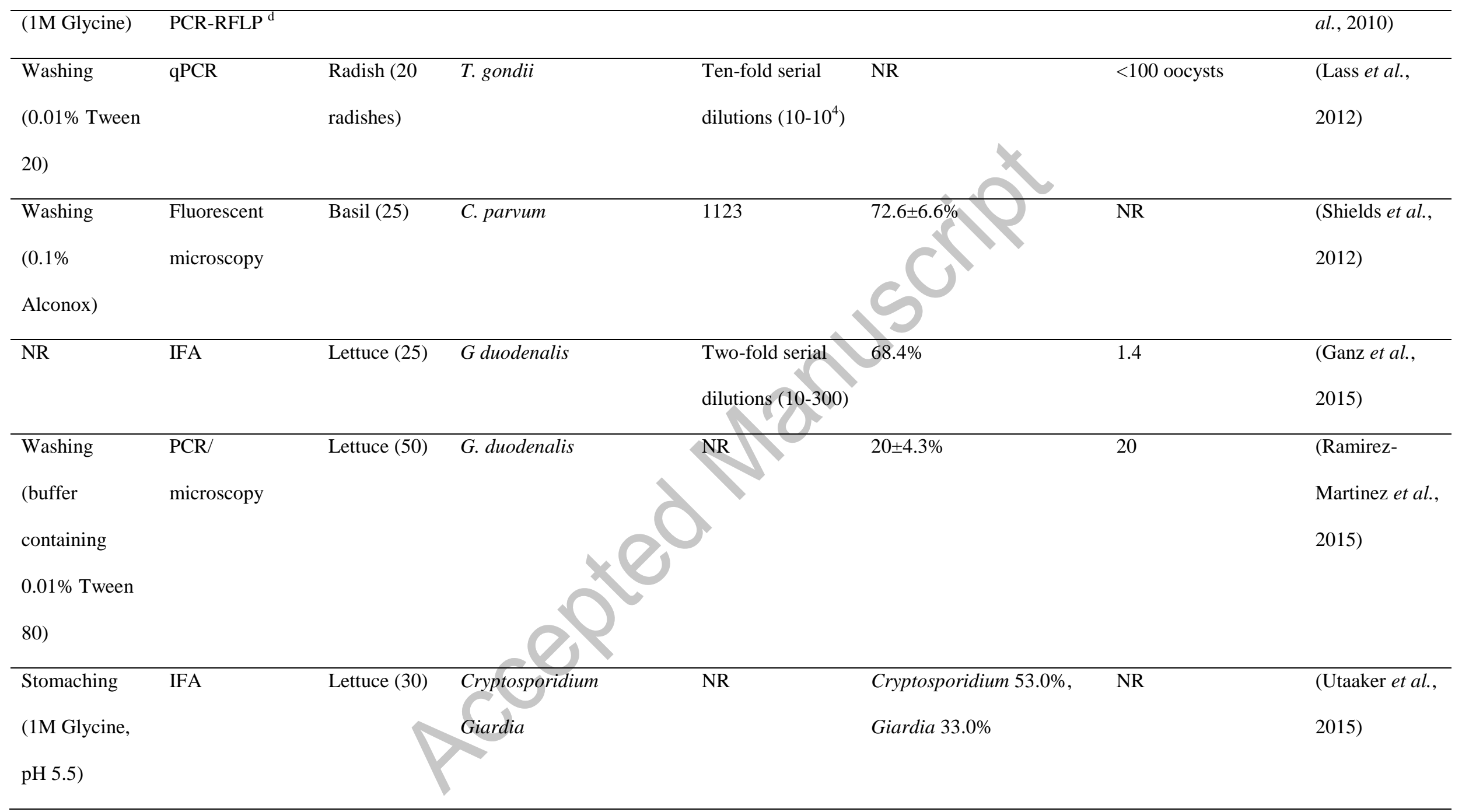




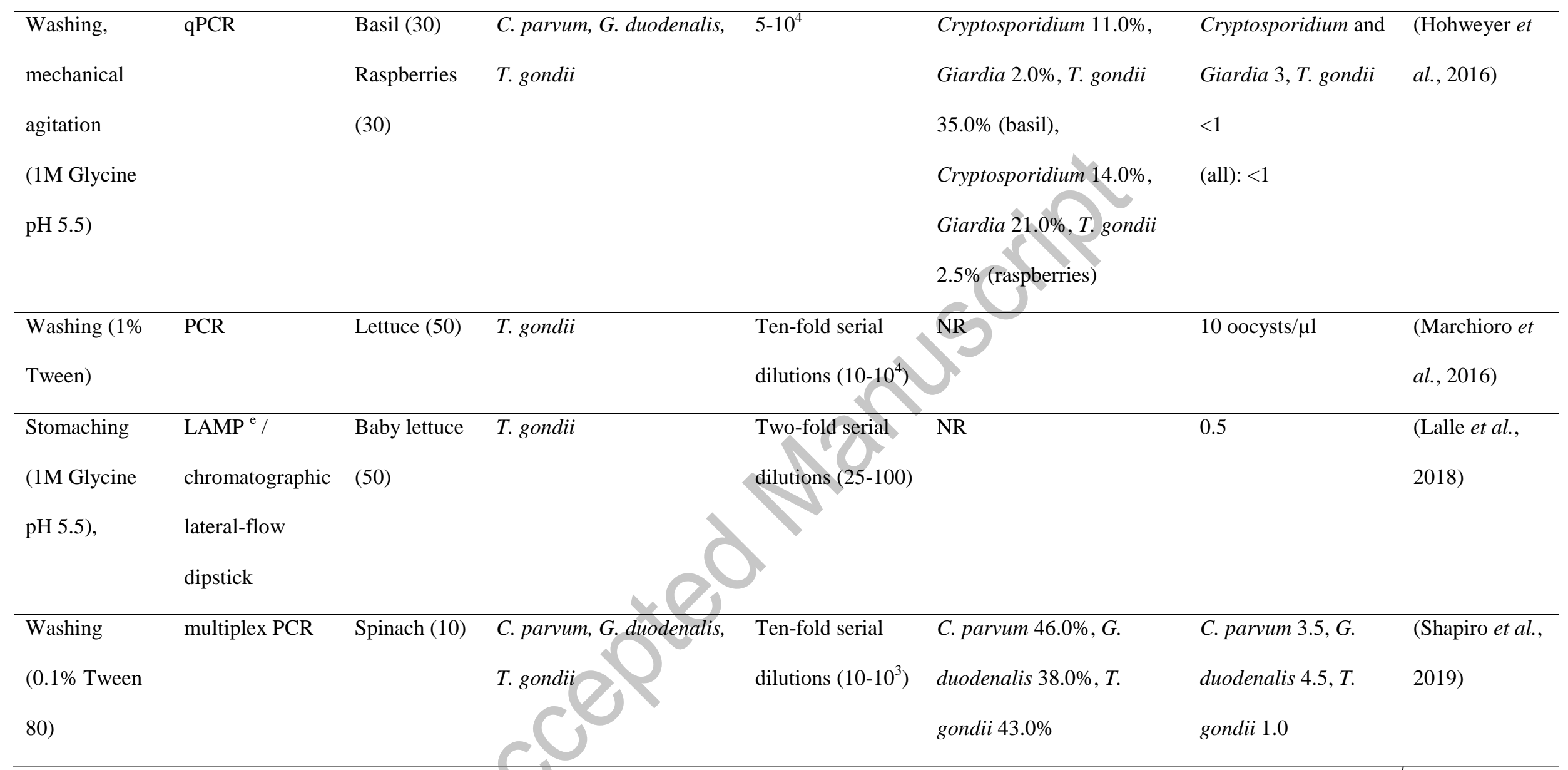

${ }^{a}$ Most studies targeted detection of one or two of the protozoan parasites, while two publications described methods for detection of the three parasites, ${ }^{b}$ Not reported, ${ }^{c}$ Immunomagnetic separation - immunofluorescence assay, ${ }^{d}$ Polymerase chain reaction-restriction fragment length polymorphism, ${ }^{e}$ Loop mediated isothermal amplification. 